\title{
A systematic review of global publication trends regarding long-term outcomes of ADHD
}

\section{Paul Hodgkins ${ }^{1 *}$, L. Eugene Arnold ${ }^{2}$, Monica Shaw ${ }^{3^{+}}$, Hervé Caci ${ }^{4}$, Jennifer Kahle ${ }^{5}$, Alisa G Woods ${ }^{5,6}$ and Susan Young ${ }^{7}$}

1 Shire Development Inc., Global Health Economics and Outcomes Research, Wayne, PA, USA

${ }^{2}$ Research Unit on Pediatric Psychopharmacology, Nisonger Center, The Ohio State University, Columbus, OH, USA

${ }^{3}$ Norgine Pharmaceuticals, Uxbridge, UK

${ }^{4}$ Hôpitaux Pédiatriques de Nice CHU Lenval, Nice, France

${ }^{5}$ BPS International, San Diego, CA, USA

${ }^{6}$ Biochemistry and Proteomics Laboratory, Chemistry and Biomolecular Science, Clarkson University, Potsdam, NY, USA

7 King's College London, Institute of Psychiatry, London, UK

\section{Edited by:}

Anne Glowinski, Washington

University School of Medicine, USA

Reviewed by:

Anne Glowinski, Washington

University School of Medicine, USA

Ravikumar Chockalingam,

Washington University, USA

*Correspondence:

Paul Hodgkins, Shire Development Inc., Global Health Economics and

Outcomes Research, Wayne, PA

19341, USA.

e-mail:phodgkins@shire.com

${ }^{\dagger}$ Dr. Monica Shaw was an employee of Shire Pharmaceuticals Ltd. at the time this analysis was conducted and at the time this manuscript was drafted.
There is increased global recognition of attention deficit hyperactivity disorder (ADHD) as a serious medical condition with long-term consequences. Although originally conceived of as a childhood disorder, ADHD is being increasingly recognized in adults. Individual geographic regions may have specific interests and objectives for the study of ADHD. A systematic review of long-term outcomes (LTOs) in ADHD was conducted to evaluate research on ADHD LTOs on a global scale. Studies that were at least 2 years in duration were examined. A total of 351 studies were identified in the final analysis. We identified nine outcomes of interest and classified studies by specific geographical regions, age groups studied and study design by region and over time. Published studies of LTOs in ADHD have increased in all geographical regions over the past three decades, with a peak number of 42 publications in 2008. This rise in publications on ADHD LTOs may reflect a rise in global interest and recognition of consequences and impairment associated with ADHD. Although many world regions have published on ADHD LTOs, the majority of studies have emerged from the US and Canada, followed by Europe. While investigators in the US and Canada were predominantly interested in drug addiction as a LTO, European researchers were more interested in antisocial behavior, and Eastern Asian investigators focused on both of these LTOs as well as self-esteem. Geographical differences in the focus of ADHD LTO studies may reflect regional variations in cultural values. Proportionally fewer prospective longitudinal studies and proportionally more retrospective and cross-sectional studies have been published in more recent decades. Finally, more studies focusing on ADHD in adolescents and adults have been conducted in recent years, and particularly adolescents in Eastern Asia. These changes in basic study design may reflect an increase in the recognition that ADHD is a lifetime chronic disorder. This systematic review analysis of publication trends in ADHD LTOs reflects geographically based interests that change over time.

Keywords: ADHD, attention deficit, hyperactivity, hyperkinetic, TDAH

\section{INTRODUCTION}

Global interest in attention deficit hyperactivity disorder (ADHD) is on the rise (Hinshaw et al., 2011). ADHD has only been recently recognized on an international scale as a serious medical condition with long-term consequences (Garcia-Jimenez et al., 2005; Wilcox et al., 2007; Curatolo et al., 2010; Davis et al., 2011; Lecendreux et al., 2011). Historical evidence, however, attests that ADHD symptoms have been described in individuals in many different countries. For example, Jean-Baptiste Poquelin, known as Molière - the French theater author - may have been one of the first people to describe a character with symptoms of ADHD in "L'étourdi ou les contretemps" (translated into English as the scatterbrain or the bungler) in as early as 1653 (Bange and Mouren, 2009). In 1798 Scottish physician Sir Alexander Crichton wrote of a disorder characterized by inattention and restlessness that affects schooling (Palmer and Finger, 2001). Heinrich Hoffman (1844-1845) was a German psychiatrist who wrote children's stories including the agitated child character known as "fidgety Phil" and the inattentive "Johnny, who looks in the air" (Thome and Jacobs, 2004). The first report of stimulant administration to children for ADHD-like symptoms was published by Charles Bradley in the US in 1937. He reported that the academic performance of students with ADHD-like symptoms immediately improved after stimulant administration (Bradley, 1937; Findling, 2008).

The first diagnostic description of what is now called ADHD occurred in The International Statistical Classification of Diseases Ninth Edition (ICD-9) and The Diagnostic and Statistical Manual of Mental Disorders, Second Edition (DSM-II) in 1965 and 
1968, respectively. ADHD was called hyperkinetic syndrome of childhood (Stubbe, 2000) or hyperkinetic reaction (DSM-II). This term remains in the current ICD-10 as hyperkinetic disorder. In the next edition, DSM-III, came the first definition of attention deficit disorder (ADD) with or without hyperactivity 1980 (Lange et al., 2010). In the DSM-III-R the term was changed to ADHD, which has persisted to the present. The DSM-IV added subtypes of predominantly hyperactive, predominantly inattentive, and combined (Lange et al., 2010). The addition of the inattentive subtype increased the number of people meeting diagnostic criteria using the DSM-III-R by approximately $24 \%$ (Lahey et al., 1994). While the definition of ADHD was not changed for the DSM-IV-TR, it is anticipated that sub-typing may expand for the upcoming 2012 DSM-V to add a fourth subtype known as inattentive-restrictive, which is characterized almost exclusively by inattentive symptoms, with minimal hyperactive symptoms (Nigg et al., 2010; APA, 2011).

DSM-IV and ICD-10 have similar criteria for inattentive, hyperactive, and impulsive symptom identification. However, the ICD-10 is stricter than the DSM-IV, with a demand for each symptom to be present across school, home, and other settings in order to be counted (Lange et al., 2010). Unlike the DSM-IVTR which allows sub-typing based on hyperactive/impulsive or inattentive predominance as well as the combination of both, ICD10 requires both inattentive and hyperactive/impulsive symptoms for diagnosis (EMEA, 2010). ICD-10 also excludes children with co-occurring conduct disorders (Stubbe, 2000) but has a parallel diagnosis of hyperkinetic conduct disorder, which would mainly reflect comorbid ADHD combined type with conduct disorder or oppositional-defiant disorder. In reflection of the more stringent ICD-10 criteria, when the MTA combined type ADHD sample was re-diagnosed by ICD criteria, only $25 \%$ met the criteria for hyperkinetic disorder or hyperkinetic conduct disorder (Santosh et al., 2005). In addition, Polanczyk et al. (2007) showed in their meta-regression analysis that ADHD prevalence differs by criteria used (DSM-III, DSM-IV, or ICD-10), and by informant (clinician versus teacher versus parents).

Almost four centuries ago, an ADHD-like pattern of behavior was described in adults by the French author Molière (Bange and Mouren, 2009). Considering more scientific and medical works, it appears that the persistence of ADHD in adulthood was recognized as soon as the beginning of the twentieth century by English (Still, 1902), French (Philippe and Paul-Boncour, 1905), and German (Kraepelin, 1909-1915) authors. Despite these observations, prior to 1972 it was still commonly viewed as a childhood disorder (Arnold et al., 1972). The first clinical trial in adults was conducted by Wender and colleagues in 1976 (Wood et al., 1976). ADHD therefore clearly affects both children and adults, occurring throughout the life-span with a prevalence of $5-10 \%$ in childhood, $4 \%$ in adults, and about $50-65 \%$ persistence (depending on whether ADHD was defined as fully symptomatic or with residual symptoms; Faraone et al., 2006; Kessler et al., 2006; Polanczyk et al., 2007; Kooij et al., 2010; Young and Amarasinghe, 2010). A recent study demonstrated that even older adults (mean age 66 years) suffer from ADHD symptoms and impairments based on measurements of professional, economic, social, and emotional well-being (Brod et al., 2011). The potential persistence of ADHD into adulthood makes long-term consequences important for study, and the global differences that exist in study design are of interest in the interpretation of ADHD long-term outcomes (LTOs). Many studies of ADHD have been conducted in the US, Canada, and Europe. The overall global recognition of the impact of ADHD is increasing, however, with more geographical regions beginning to appreciate the consequences of ADHD on society.

The attention lapses, hyperactivity-impulsiveness, or combination of symptoms caused by ADHD (APA, 2000; WHO, 2010) can lead to wide-ranging negative long-term life consequences (Rasmussen and Gillberg, 2000; Mill et al., 2006). Prior focus for the treatment of ADHD has been on symptomatic control. Patient management has shifted in recent years to include more focus on functional impairment. A negative impact on psycho-social, achievement, and self evaluation domains has been reported by parents of children with ADHD (Danckaerts et al., 2010). Functional impairment in multiple domains has been measured with tools such as functional magnetic resonance imaging, electrophysiology, and tests of cognitive performance, although these are not currently used as diagnostic tools (EMEA, 2010).

The differences in recognition of ADHD could be one factor that influenced reported prevalence in different world regions. For example, Polanczyk et al. (2007) showed in their meta-regression analysis that prevalence did differ when comparing different world regions. This study showed that the North American rate (6.2\%) was only slightly higher than the European rate (4.6\%). The highest rates of ADHD diagnosis were observed in Africa (8.5\%) and South America (11.8\%), but with a wide range of prevalence rates between studies. According to Polanczyk et al. (2007), the overall worldwide prevalence of ADHD is 5.3\%. The recent epidemiological studies across the world support the notion that ADHD is a ubiquitous disorder and not merely a Northern American social construct (Moffitt and Melchoir, 2007).

The current systematic review was performed with the goal of: (1) identifying peer-reviewed studies reporting LTOs (two or more years) for people with ADHD published from 1980 through 2010, and (2) to address the following research question via comprehensive analysis of all studies identified; are there differences in outcomes studied by region, either in total or over time?

\section{MATERIALS AND METHODS}

To systematically identify published studies that examined LTOs (i.e., life consequences) of participants with untreated or treated ADHD, an extensive search of 12 literature databases was performed using a strategy based on the following inclusion and exclusion criteria. Only studies identified in these databases using electronic search engines and this search strategy were included. Studies including a group of participants with ADHD as determined by each study's authors using any diagnosis criteria were included. To ensure a basic level of study quality, only peerreviewed studies and only studies utilizing a comparator group (e.g., non-ADHD controls) or comparison measure (e.g., pretreatment baseline) were included. Studies of participants that had received any or no ADHD treatment were included. Longitudinal studies with prospective follow-up or retrospective measures of 2 years or more, cross-sectional studies comparing participants of two ages differing by 2 years or more, or 
single cross-sectional studies of participants $\geq 10$-years-old were included. Primary research articles published in English from January 1980-December 2010 inclusive, with available full-text were included. Studies examining symptoms only and not outcomes were excluded. Studies in which ADHD was not a primary condition of the study participants, but was secondary to another condition (e.g., intellectual disabilities or bipolar disorder), were excluded. Animal studies, case studies, and studies including only children younger than 2 years old were excluded. Meta-analyses and literature review studies were also excluded.

The search strategy for study identification was as follows. Inclusionary terms were: (1) names of the condition; ADD (captured all versions of ADHD), hyperkinesis or hyperkinetic, TDAH (trouble déficit de l'attention/hyperactivité in French or trastorno por déficit de atención con hiperactividad in Spanish, DAH (déficit de l'attention/hyperactivité in French or déficit de atención con hiperactividad in Spanish), DAA (déficit de l'Attention/activité in French or déficit de atención y actividad in Spanish), and (2) LTOs; long-term, longitudinal, education, degree, socioeconomic, salary, divorce, relationship, hobbies, criminality, arrest, incarceration, automobile, car, driving, citation, weight, obesity, suicide, drug abuse, addiction, substance abuse, alcoholism, and (3) comparator condition or group; control, proband, placebo, untreated, no treatment, pre-treatment, comparator, follow-up, normal, compare. Exclusionary terms were: (1) developmental, causal, or symptom terms; neuroanatomy, neuropathology, molecular, gene, development, etiology, preclinical, dose-finding, reaction time, and (2) unsuitable publication types; reprint, review, conference presentation. A more detailed explanation of the search methodology is available upon request. All references retrieved are included in the appendix.

To identify as many studies as possible, the search utilized 12 databases: Academic Search Premier, CINAHL, Cochrane CRCT (including EMBASE), Criminal Justice Abstracts, ERIC, MEDLINE, Military and Government collection, NHS Economic Evaluation database, PsycARTICLES, PsycINFO, SocINDEX, and Teacher Reference Center. Two search engines were used to search MEDLINE. Duplicates were eliminated electronically and manually. Additional unsuitable publication types were eliminated manually, including editorials, comments, reviews, non-peer-reviewed articles, and letters.

Based primarily on title and abstract, remaining studies were manually reviewed and included based on the agreement of two researchers. Each study's data was extracted into a database; data collected included: (1) study location (country of origin), (2) study sample size, (3) study length, (4) participant's age range, (5) study support, (6) diagnostic criteria, (7) study type (longitudinal, crosssectional, prospective, retrospective), (8) outcome measures, (9) outcome results, (10) comparator type, (11) treatment type, and (12) treatment duration. Similar outcome measures were grouped together.

For the purpose of examining studies of ADHD originating in different geographical regions of interest, studies were grouped by location according to the UN Geoscheme (UN, 2011). Major regions included Northern America (United States and Canada excluding Mexico), Europe, Eastern Asia, Western Asia, Oceania (New Zealand and Australia), and Latin America (including
Mexico) and the Caribbean. International collaborations were also of interest.

For the purpose of examining studies of ADHD involving participants of different ages, the age range of participants was noted whenever possible and mid-range age was calculated. If the age range was not reported, the mean age was used. The midrange/mean age was used to group each study into one of three age groups: children were 6- to 12-years-old, adolescents were between 13- and 17-years-old, and adults were above 17 years old. For midrange ages $18-22$, the minimum and maximum ages were also taken into account. If the minimum age was 16 years or younger and the maximum age was below 30 years, then the study was grouped with adolescent studies, rather than adult studies. For further analysis of studies of adults specifically, the age range/mean age was used directly to group studies into three adult groups: transitional adults (18- to 24-years-old), young adults (25- to 44-years-old), and mature adults (45- to 64-years-old).

\section{RESULTS \\ SEARCH RESULTS}

The initial search yielded 7272 citations. Electronic and manual removal of duplicates resulted in removal of 1805 citations. An additional 341 citations were removed according to basic criteria (exclusion of reviews, supplements, case studies, animal studies, editorials, not peer-reviewed articles, not English language) leaving 5126 citations. The titles and abstracts of these 5126 studies were reviewed and 4775 citations were excluded, leaving a total of 351 studies suitable for inclusion according to full inclusion criteria: studies included ADHD participants, reported LTOs or life consequences, and included a comparator measure or group. Study population size ranged from 6 to $1,026,873$ participants and longitudinal study duration ranged from 2 to 40 years.

\section{ADHD OUTCOME STUDIES BY GEOGRAPHICAL REGION}

Outcome measures were organized into nine main groups based on common outcome characteristics (Table 1).

Studies were grouped according to the major geographical regions described above and on the number of studies that were located in specific geographical regions. The countries of origin (31 total) of all the studies included in the final data set in each major geographical region are presented in Table 2. In Northern America (US and Canada, excluding Mexico) and Europe, there was a steady overall rise in studies of LTOs of ADHD published between 1980 and 2010, with a marked rise in the late 1990s. In Eastern Asia there was a small increase in studies over time also, starting in 2005 (Figure 1). The number of LTO studies published globally peaked in 2008 with 42 studies published that year. The number of studies published in all of the regions shown is continuing to rise in general. Studies involving international collaborations started to be published in 2002 .

The interests of specific geographical regions in the nine identified outcome groups were examined (Figure 2). The total number of outcome results was highest for non-medicinal drug use/addictive behavior, followed by academic outcomes, antisocial behavior, social function, occupation, self-esteem, driving, public services use, and obesity. The outcome results reported in the highest proportion of studies from Europe were regarding 
Table 1 | Grouping of outcome results.

\section{Outcome groups}

Academic

Antisocial behavior

Driving

Non-medicinal drug use/addictive behavior

Obesity

Occupation

Public services use

Self-esteem

Social function

\section{Outcome result examples}

Achievement test scores, grade point average, failed grades, years of schooling, degrees

School expulsion, delinquency, self-reported crimes, arrests, detainment, incarceration, repeat convictions Accidents, traffic violations, license suspensions, driving habits and skill, driving record

Use, abuse, and dependence on alcohol, cigarettes, marijuana, stimulants, or illicit drugs; age at first use; multiple substance use; gambling

Body mass index (BMI), weight

Employment, military service, job changes, occupation level, socioeconomic status Justice system, emergency health care, financial assistance

Self-esteem scales, self-perception, suicide ideation, suicide attempts, suicide rate

Relationships, peer nomination scores, marital status, multiple divorces, activities, hobbies

Table 2 | Study country of origin by world region (UN, 2011).

Northern America

Europe

Latin America and Caribbean

Eastern Asia

Western Asia

Oceania

\section{Canada, United States}

Austria, Belgium, Denmark, European Russia, Finland, France, Germany, Greece, Iceland, Italy, Netherlands, Norway, Spain, Sweden, Switzerland, United Kingdom

Mexico, Puerto Rico, Brazil, Colombia

China, Japan, South Korea, Taiwan

Israel, Lebanon, Turkey

Australia, New Zealand

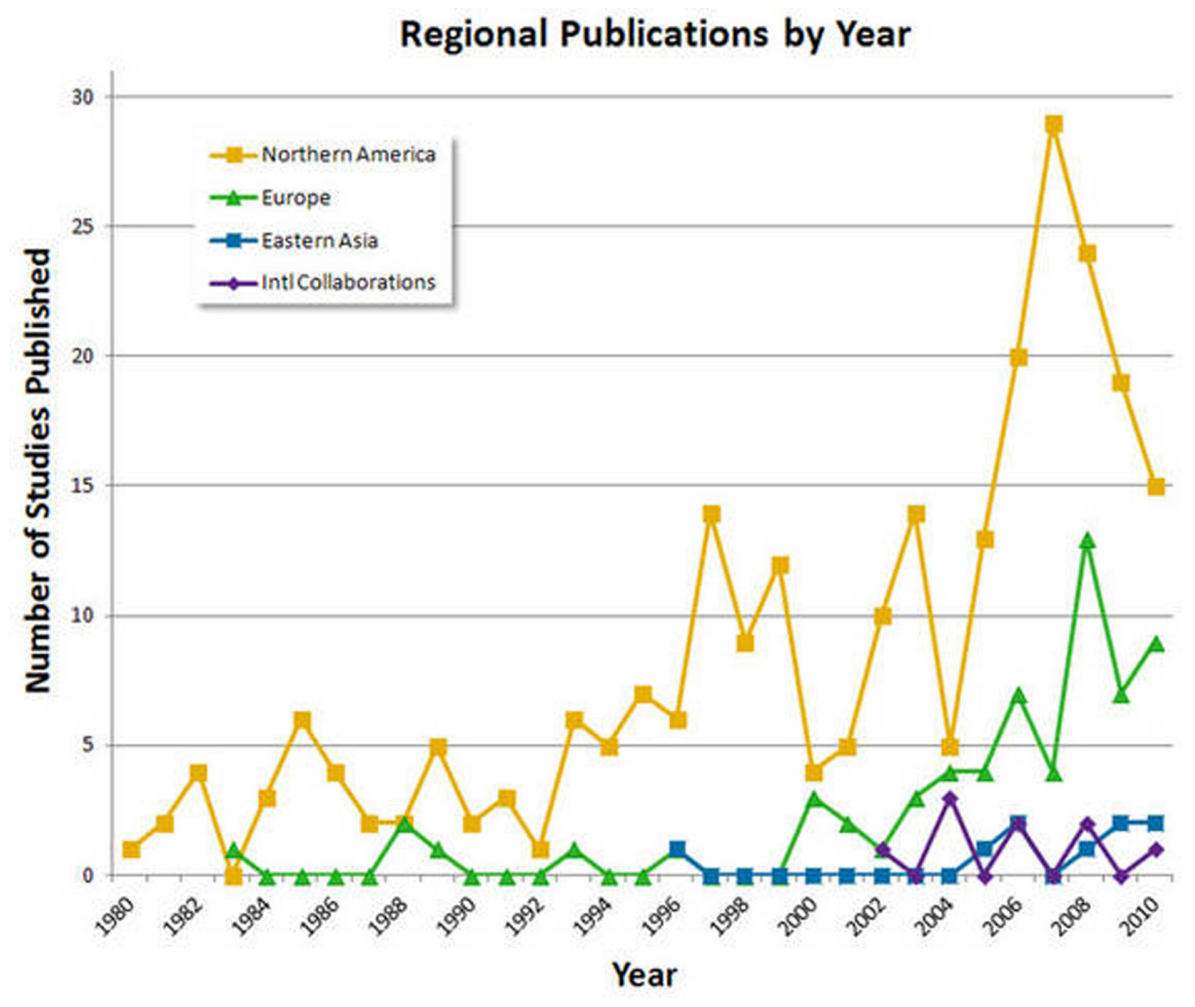

FIGURE 1 | Total number of studies per year by geographical region. There was a marked rise in studies of long-term outcomes of ADHD published worldwide between 1980 and 2010. The number of long-term outcome studies published globally peaked in 2008 with 42 studies published that year. The number of studies published in all of three regions shown appears to be generally continuing to rise. Studies involving international collaborations started being published in 2002. 


\section{Outcome Groups by Region}

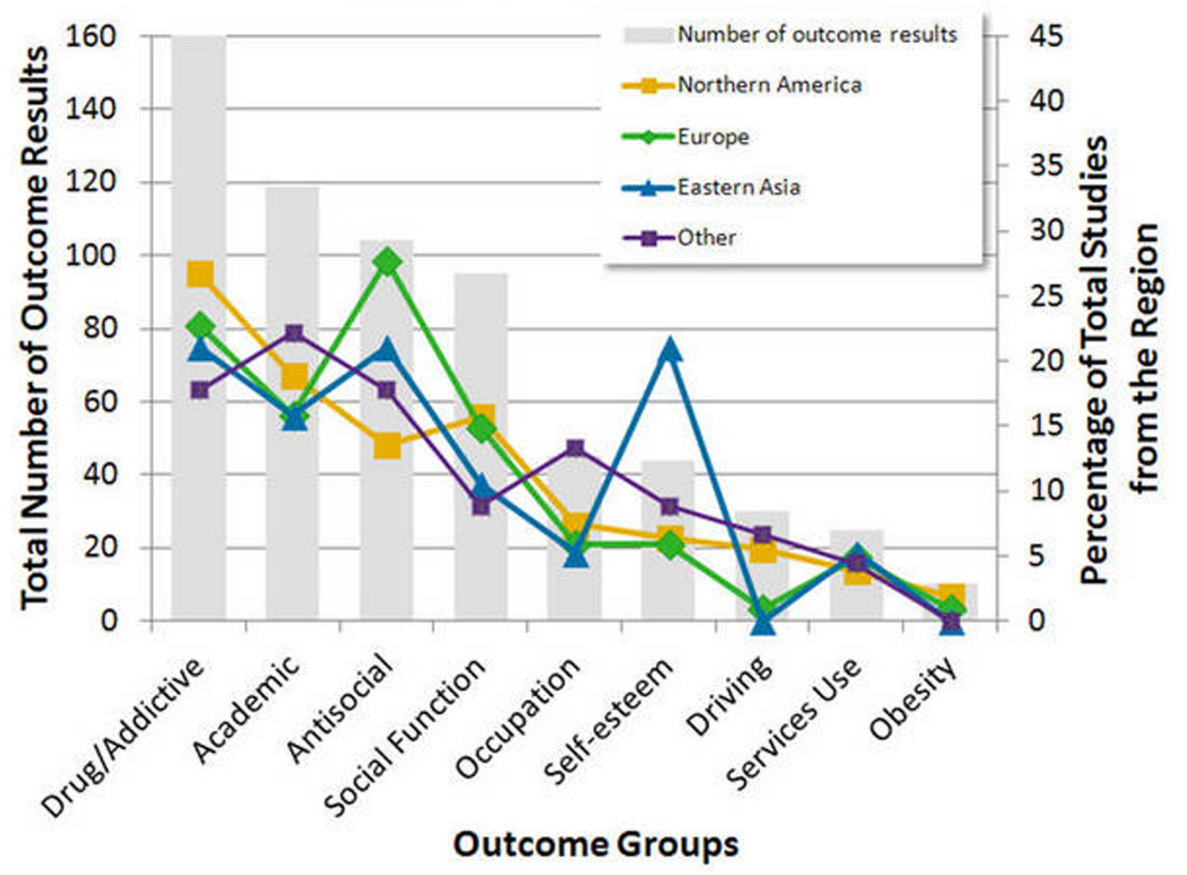

FIGURE 2 | Interests of specific geographical regions. The total number of outcome results was highest for drug use/addictive behavior, followed by academic outcomes, antisocial behavior, social function, occupation, self-esteem, driving, services use, and obesity. In Europe, the most studies examined antisocial behavior; in Northern America non-medicinal drug use/addictive behavior; and in Eastern Asia self-esteem, non-medicinal drug use/addictive behavior, and antisocial behavior. The highest proportion of studies from all other regions together focused on academic outcomes. antisocial behavior (28\%); from Northern America were regarding non-medicinal drug use/addictive behavior (27\%); from Eastern Asia were regarding self-esteem (21\%), non-medicinal drug use/addictive behavior (21\%), and antisocial behavior (21\%); and from all other regions together ("Other") were regarding academic outcomes $(22 \%)$.

\section{CHANGES IN STUDY DESIGN OVER TIME}

Changes in the broad categories of study design (cross-sectional, longitudinal, prospective, and retrospective) utilized over time by decade (from 1981 to 2010) are shown in Figure 3 (in excluding 1980 only one study was omitted). Proportionally fewer prospective longitudinal studies have been published over time $(77,64$, 46\% for decades 1981-1990, 1991-2000, and 2001-2010, respectively) and proportionally more retrospective and cross-sectional studies have been published in more recent decades (23, 36, 54\% for decades 1981-1990, 1991-2000, and 2001-2010, respectively). No large differences in study design were observed according to geographical region (Northern America, Europe, and all other regions), with longitudinal prospective studies being most prevalent for all regions (52-57\%), followed by longitudinal retrospective (21-28\%) and cross-sectional (19-21\%; data not shown).

\section{CHANGES IN AGE GROUP STUDIED OVER TIME}

Figure 4 shows an analysis of subject age by year of the study published. Over time, there has been a clear trend to publish more adolescent and adult studies. In contrast, the number of published studies of children remained relatively stable. For example, in the 3 years 1985-1987, 5 studies of children and 7 of adolescents or adults were published, while in the 3 years 2005-2007, 8 studies of children and 78 studies of adolescents or adults were published.

The full range of ages of participants in all the studies in the present analysis was from 0 - to 84-years-old, including ages at entry and follow-up of participants in longitudinal prospective studies. Based directly on the mid-range/mean age of study participants 18 years or older, 81 of 197 (41\%) studies were of transitional adults (18-24 years), 92 (47\%) were of young adults (25-44), and $24(12 \%)$ were of mature adults (45-64 years). No studies had a mid-range/mean age of participants older than 64 years.

Studies of all three designs have been conducted in adults, including prospective, retrospective, and cross-sectional analyses. As might be expected, of all the retrospective studies, most (72\%) have been conducted in adults. Of all the prospective studies, most (49\%) have been conducted in adolescents (Table 3).

Finally, the proportion of studies of different age groups in Northern America, Europe, Eastern Asia, and the rest of the world is presented in Figure 5. The proportion of studies of children is highest in Northern America (17\%) compared to $8 \%$ in "Other" countries around the globe (includes: Mexico, Puerto Rico, Colombia, Brazil, Israel, Lebanon, Turkey, Australia, and New Zealand). The proportion of studies of adults is highest in Northern America (48\%) and Europe (50\%), while studies from Eastern Asia and "Other" countries include a large proportion of studies of adolescents (60 and 58\%, respectively). 
We considered two possible explanations for the greater proportion of studies of adolescents in East Asia and "Other" countries; neither of which appear to account for the trend upon examination of the studies in the database, as follows: the large proportion of studies of adolescents in Eastern Asia and "Other" countries was not due to a larger proportion of these studies being prospective longitudinal studies, as might be inferred from data presented in Table 3. The proportion of different study designs of

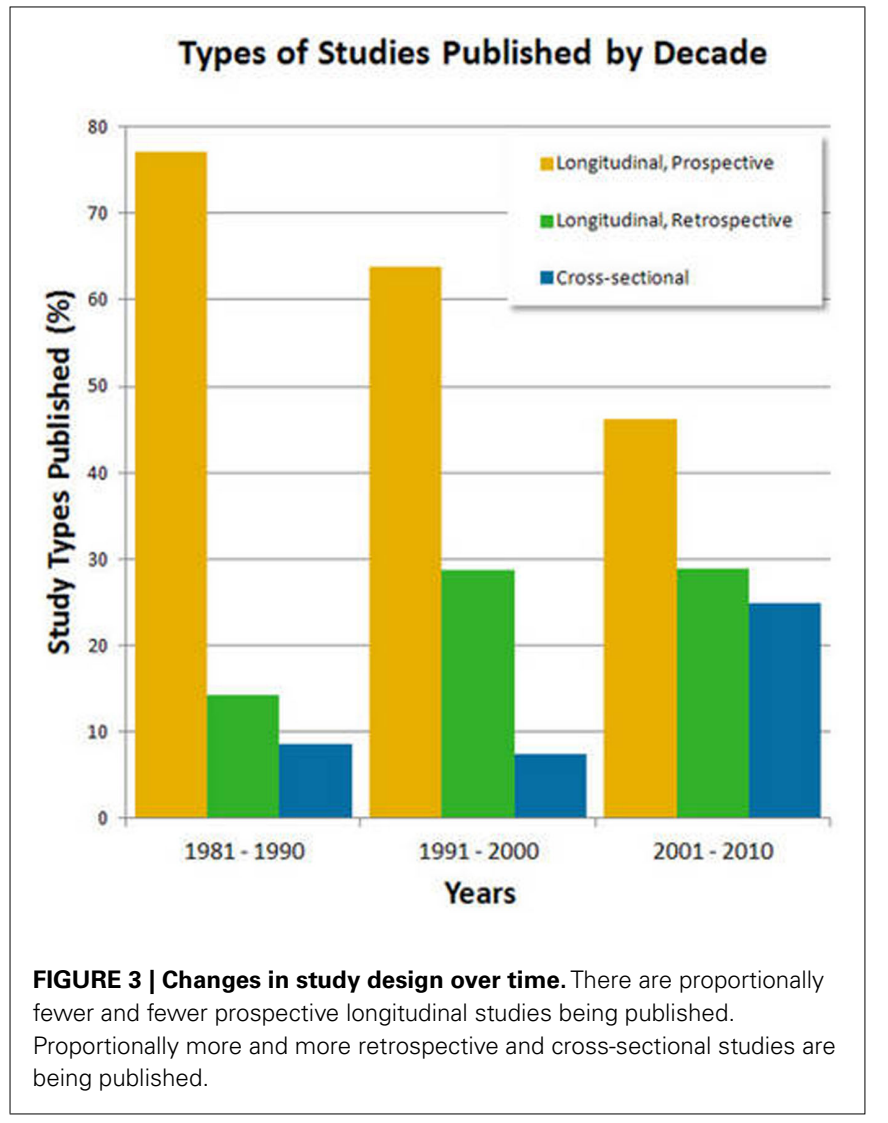

adolescent studies from these regions was very similar to the proportion of different study designs found in all world regions $(50 \%$ prospective longitudinal, $25 \%$ retrospective longitudinal, and 25\% cross-sectional). Nor does it appear to be due to an artifact of longitudinal prospective studies ending with participants at different ages at follow-up in East Asia and "Other" countries versus Northern America and Europe. The mean mid-range/mean age at follow-up for East Asia and "Other" countries was 16.9 years, not substantially different than that for Northern America and Europe, which was 17.9 years.

\section{DISCUSSION}

\section{STUDIES OF ADHD LTOS OVER TIME}

This analysis clearly shows that numerous studies of LTOs in ADHD already exist, and that studies of this topic have increased steadily from 1980 to the present time, with a peak increase in studies published in 2008. When published studies are considered by geographical regions, a similar pattern in terms of peak publication is observed, although most studies have been conducted in Northern America. As detailed in the introduction, the prevalence of ADHD has been estimated by a research group from Brazil, who found ADHD present in all nations (Polanczyk et al., 2007). Thus, these results may be due to greater acceptance of ADHD as a disorder for study in the US and Canada or perhaps greater availability for funding for ADHD-related studies specifically. These results may also reflect a general larger proportion of biomedical research studies coming from the US in all therapeutic fields.

The incidence of reported $\mathrm{ADHD}$, more recently including adult $\mathrm{ADHD}$, has increased in the US over time, undoubtedly spurring the interest in study of ADHD (Boyle et al., 2011; Montejano et al., 2011). Interestingly, even within the US itself ethnic differences in ADHD diagnosis exist, with more ADHD diagnoses in White American youths versus Hispanic American youths (Stevens et al., 2004). A recent report described higher incidence in non-Hispanic white children versus non-Hispanic black children and lower incidence in Mexican children versus other groups (Akinbami et al., 2011).

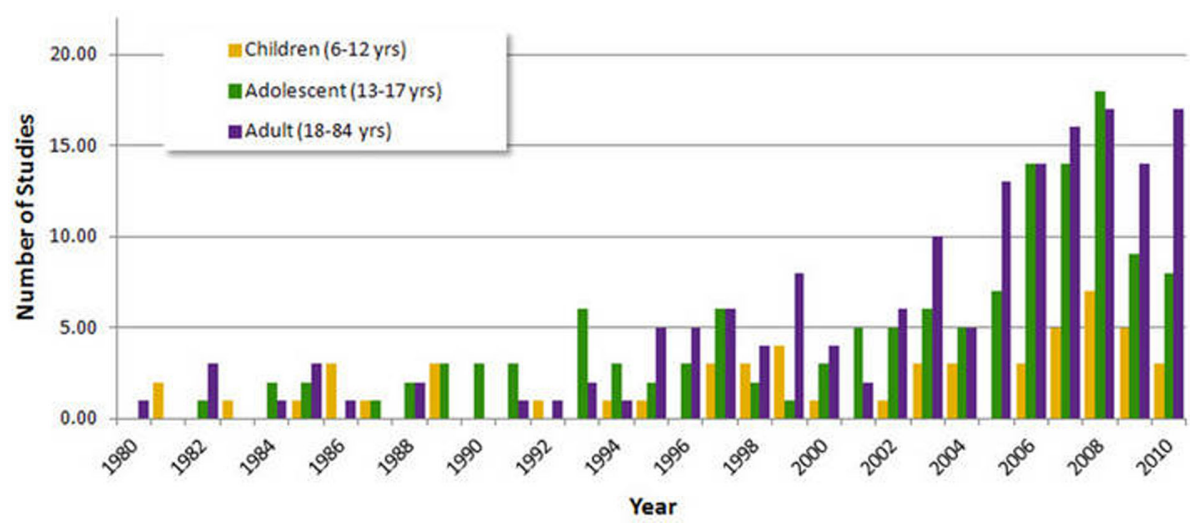

FIGURE 4 | Participant ages by year. There are more and more studies of adolescents and adults being published, while the number of studies of children remains relatively stable. Adults are often studied retrospectively, which may explain the results shown in Figure $\mathbf{3}$. 


\section{ADHD LTO INTERESTS OF SPECIFIC GEOGRAPHICAL REGIONS}

When we examined the focus of interest for specific geographic regions, we observed that in Europe, antisocial behavior was of the highest interest. The largest amount of research in the US was concerning non-medicinal drug use/addictive behavior. In Eastern Asia there appeared to be a balance of research in antisocial behavior, non-medicinal drug use/addictive behavior, and self-esteem. Other regions had the greatest research in academic outcomes. These "other" countries included those in Western Asia (Lebanon, Israel, Turkey), Oceania (Australia, New Zealand), and Latin America and the Caribbean (Puerto Rico, Mexico, Colombia, Brazil). The differences in study emphasis observed may have to do with geographic variations in the cultural expectations of children and adults with ADHD, but may also reflect the emphasis of government policies and attempts at cost reduction in specific sectors of society (such as in the prison system; Young et al., 2011a). One can additionally speculate about the types of studies that have been included overall. For example, the rather low number of driving

Table 3 | Number of studies of different design by different age groups.

\begin{tabular}{llll}
\hline & $\begin{array}{l}\text { Longitudinal, } \\
\text { prospective }\end{array}$ & $\begin{array}{l}\text { Longitudinal, } \\
\text { retrospective }\end{array}$ & $\begin{array}{l}\text { Cross- } \\
\text { sectional }\end{array}$ \\
\hline Adults (18-84 years) & 51 & 69 & 41 \\
Adolescents (13-17 years) & 91 & 20 & 20 \\
Children (6-12 years) & 43 & 7 & 6
\end{tabular}

studies was included because this is more likely to be studied in short-term than long-term studies. The high number of studies on non-medicinal drug-use/addictive behavior may be due to fears of stimulant abuse.

\section{AGE-RELATED FOCUS OF ADHD LTO STUDIES}

The present results indicate that there has been a general shift in interest to the effects of ADHD in transitional and young adults. There were limited studies (24 total) in adults aged 45 and older, however, a recent study of ADHD in adults with a mean age of 66 demonstrated life burden of decreased finances, increased illness, lower educational, and job status as well as being socially isolated (Brod et al., 2011). Current data indicates responsiveness of this population to treatment that is similar to younger populations (Manor et al., 2011). Interest in adult ADHD has risen; no doubt due to the impact of ADHD on work, daily living, family living, and relationships (Young et al., 2003; Rosler et al., 2010).

The present results also indicate that over time there has been a shift in study design from prospective longitudinal studies to retrospective longitudinal studies. This may be explained by the analysis described in Figure 4, which shows the increasing interest in the effects of ADHD in adults and Table 3, which shows that studies of ADHD in adults are largely retrospective studies. Studies of ADHD in adults often necessarily utilize a retrospective design, particularly if ADHD is identified when the participants are adults, or if symptoms that existed in childhood are evaluated retrospectively in adults looking back on their childhood.

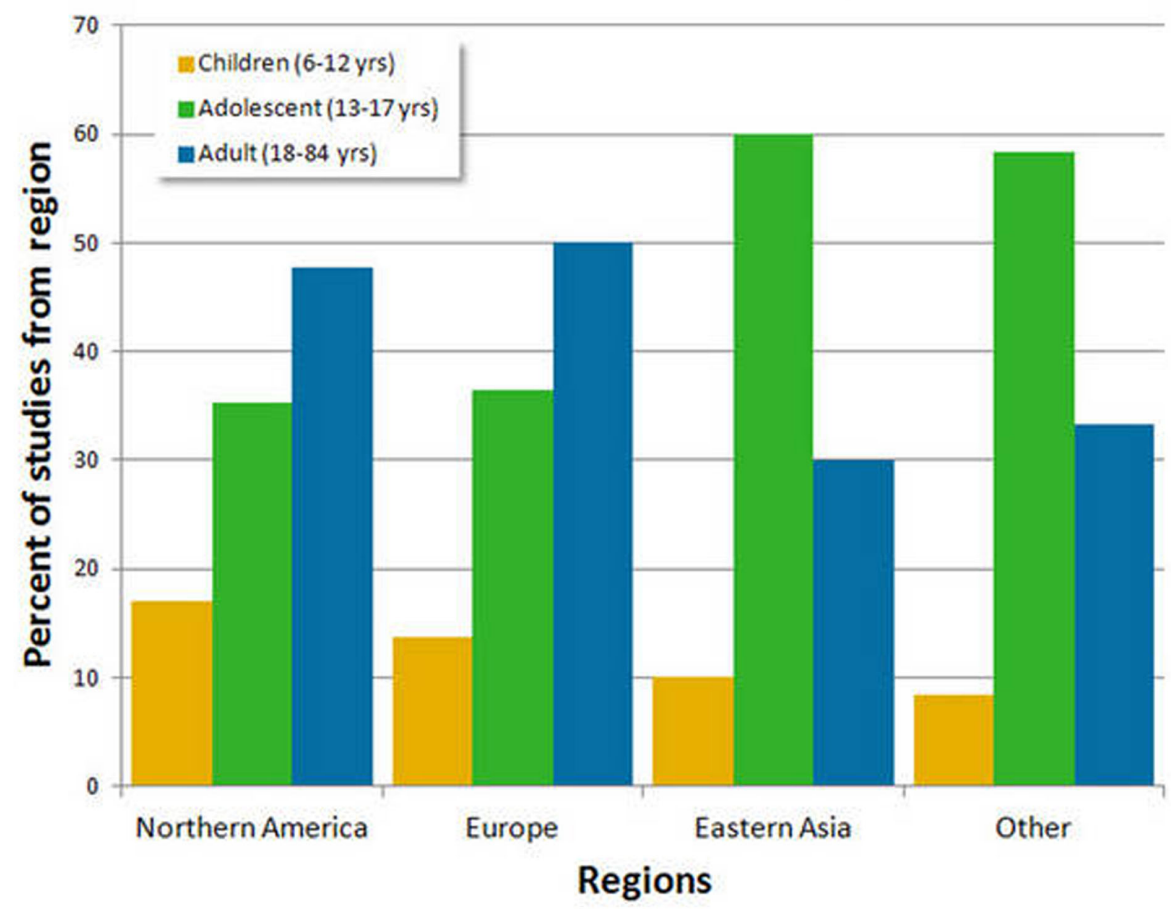

FIGURE 5 | Participant ages by region. The proportion of studies of different age groups is similar between Northern America and Europe, but studies

from Eastern Asia and "Other" countries around the globe include a large proportion of adolescents and fewer children and adults. 
Finally, we found that in Northern America and Europe, the bulk of studies have been conducted in adult populations; then adolescents followed by children, whereas in Eastern Asia and all other regions, most studies have been conducted in adolescent populations (Figure 5). This trend may reflect the interests of specific countries, however, the reasons for this trend are not clear. This may reflect differences in service provision, with more adult services being available/set up in western countries. It may be due to the availability of sources of data in specific regions and the need for immediately publishable results. Specific regions of the world may be just starting to understand $\mathrm{ADHD}$ and in other countries across the world, the trend has been to start off with study of ADHD in children and then gradually move to study of ADHD in adults.

\section{CONSIDERATION OF POSSIBLE BIASES AND LIMITATIONS}

Biases and limitations need to be evaluated regarding the studies included. Naturally, compiling studies with different designs has benefits and limitations. When reviewing this analysis, it is important to consider that the studies extracted have different geographical populations, different numbers of subjects, different investigators, and numerous other different characteristics in terms of their design. Although the compilation of studies must be viewed with appropriate caveats regarding differences between study designs, there is value in being able to view a comprehensive body of literature together in one place; hence our rationale for conducting this analysis and presenting the results graphically rather than only descriptively.

Publication and cultural bias may have resulted from evaluating only studies published in English. Also, the analysis excluded unpublished conference presentations. Search engine and literature database bias may have occurred, since only studies included in databases were included. We reduced this bias through extensive searching of a total of 12 databases. In addition, our search

\section{REFERENCES}

Akinbami, L. J., Liu, X., Pastor, P. N., and Reuben, C. A. (2011). Attention Deficit Hyperactivity Disorder Among Children Aged 5-17 Years in the United States, 1998-2009, NCHS data brief, no 70 (Hyattsville, MD: National Center for Health Statistics).

APA. (2000). DSM-IV-TR. Washington: American Psychiatric Association.

APA. (2011). Attention Deficit/ Hyperactivity Disorder. Bethesda, MD: American Psychiatric Association.

Arnold, L. E., Strobl, D., and Weisenberg, A. (1972). Hyperkinetic adult. Study of the "paradoxical" amphetamine response. JAMA 222, 693-694.

Bange, F., and Mouren, M.-C. (2009). Les hyperactifs à travers la littérature et l'histoire, in Comprendre et soigner l'hyperactivité chez l'adulte. Paris: Dunod.

Boyle, C. A., Boulet, S., Schieve, L. A., Cohen, R. A., Blumberg, S. J.,

relied on search engines for "peer-reviewed" articles, which may have erroneously excluded some studies that were, in fact, peerreviewed. All the studies included in the present analysis were confirmed to be peer-reviewed.

\section{FUTURE DIRECTIONS}

This analysis examined geographical publication trends for studies of LTOs in ADHD. It supports a trend for increased study over time of this topic across all regions, differences in the focus of specific geographical regions, a shift to a focus on effects of ADHD in adults and more retrospective studies being conducted. Further analyses of this database is appropriate to address pertinent research questions such as the impact of pharmacological and/or psychological treatment on ADHD LTOs, and whether specific LTOs are more or less responsive to treatment. Further analysis may include comparisons of outcomes of participants who have been treated with drugs with different mechanisms of action, for example.

It is encouraging that research is now taking a life-span perspective. With studies starting to report ADHD outcomes in older adults, future research should focus on longer-term outcomes and, in particular, treatment of ADHD in the longer-term. However, the life-span perspective of research has not been directly paralleled with service provision. Mechanisms that translate research findings into evolving clinical practice, and service provisions that meet the needs of patients who must transition between services need to be better established (Young et al., 2011b) as this seems to be the current challenge faced by practitioners in the field.

\section{ACKNOWLEDGMENTS}

The authors would like to thank Nicholas Callamaras, $\mathrm{PhD}$, for help with identifying included studies, analyses, and drafting figures, Anne Thomson for extensive assistance with reference retrieval and Amina Elsner, MD, for constructive comments.

Eur. Child Adolesc. Psychiatry 19, 83-105.

Davis, J. M., Cheung, S. F., Takahashi, T., Shinoda, H., and Lindstrom, W. A. (2011). Cross-national invariance of attention-deficit/hyperactivity disorder factors in Japanese and U.S university students. Res. Dev. Disabil. 32, 2972-2980.

EMEA. (2010). Guideline on the Clinical Investigation of Medicinal Products for the Treatment of Attention Deficit Hyperactivity Disorder (ADHD). London: European Medicines Agency.

Faraone, S. V., Biederman, J., and Mick, E. (2006). The age-dependent decline of attention deficit hyperactivity disorder: a meta-analysis of follow-up studies. Psychol. Med. 36, 159-165.

Findling, R. L. (2008). Evolution of the treatment of attentiondeficit/hyperactivity disorder in children: a review. Clin. Ther. 30, 942-957.
Garcia-Jimenez, M. C., Lopez-Pison, J., and Blasco-Arellano, M. M. (2005). The primary care paediatrician in attention deficit hyperactivity disorder. An approach involving a population study. Rev. Neurol. 41, 75-80.

Hinshaw, S. P., Scheffler, R. M., Fulton, B. D., Aase, H., Banaschewski, T., Cheng, W., Mattos, P., Holte, A., Levy, F., Sadeh, A., Sergeant, J. A., Taylor, E., and Weiss, M. D. (2011). International variation in treatment procedures for ADHD: social context and recent trends. Psychiatr. Serv. 62, 459-464.

Kessler, R. C., Adler, L., Barkley, R., Biederman, J., Conners, C. K., Demler, O., Faraone, S. V., Greenhill, L. L., Howes, M. J., Secnik, K., Spencer, T., Ustun, T. B., Walters, E. E., and Zaslavsky, A. M. (2006). The prevalence and correlates of adult ADHD in the United States: results from the National Comorbidity Survey Replication. Am. J. Psychiatry 163, 716-723. 
Kooij, S. J., Bejerot, S., Blackwell, A., Caci, H., Casas-Brugue, M., Carpentier, P. J., Edvinsson, D., Fayyad, J., Foeken, K., Fitzgerald, M., Gaillac, V., Ginsberg, Y., Henry, C., Krause, J., Lensing, M. B., Manor, I., Niederhofer, H., Nunes-Filipe, C., Ohlmeier, M. D., Oswald, P., Pallanti, S., Pehlivanidis, A., RamosQuiroga, J. A., Rastam, M., RyffelRawak, D., Stes, S., and Asherson, P. (2010). European consensus statement on diagnosis and treatment of adult ADHD: the European Network Adult ADHD. BMC Psychiatry 10, 67. doi:10.1186/1471-244X-10-67

Kraepelin, E. (1909-1915). Psychiatrie: ein Lehrbuch fur Studierende und Arzte. Leipzig: Barth.

Lahey, B. B., Applegate, B., Mcburnett, K., Biederman, J., Greenhill, L., Hynd, G. W., Barkley, R. A., Newcorn, J., Jensen, P., Richters, J., Garfinkel, B., Kerdyk, L., Frick, P. J., Ollendick, T., Perez, D., Hart, E. L., Waldman, I., and Shaffer, D. (1994). DSM-IV field trials for attention deficit hyperactivity disorder in children and adolescents. Am. J. Psychiatry 151, 1673-1685.

Lange, K. W., Reichl, S., Lange, K. M., Tucha, L., and Tucha, O. (2010). The history of attention deficit hyperactivity disorder. Atten. Defic. Hyperact. Disord. 2, 241-255.

Lecendreux, M., Konofal, E., and Faraone, S. V. (2011). Prevalence of attention deficit hyperactivity disorder and associated features among children in france. J. Atten. Disord. 15, 516-524.

Manor, I., Rozen, S., Zemishani, Z., Weizman, A., and Zalsman, G. (2011). When does it end? Attention-deficit/hyperactivity disorder in the middle aged and older populations. Clin. Neuropharmacol. 34, 148-154.

Mill, J., Caspi, A., Williams, B. S., Craig, I., Taylor, A., Polo-Tomas, M., Berridge, C. W., Poulton, R., and Moffitt, T. E. (2006). Prediction of heterogeneity in intelligence and adult prognosis by genetic polymorphisms in the dopamine system among children with attention-deficit/hyperactivity disorder: evidence from 2 birth cohorts. Arch. Gen. Psychiatry 63, 462-469.

Moffitt, T. E., and Melchoir, M. (2007). Why does the worldwide prevalence of childhood attention deficit hyperactivity disorder matter? Am. J. Psychiatry 164, 856-858.

Montejano, L., Sasané, R., Hodgkins, P., Russo, L., and Huse, D. (2011). Adult ADHD: prevalence of diagnosis in a US population with employer health insurance. Curr. Med. Res. Opin. 27(Suppl. 2), 5-11.

Nigg, J. T., Tannock, R., and Rohde, L. A. (2010). What is to be the fate of ADHD subtypes? An introduction to the special section on research on the ADHD subtypes and implications for the DSM-V. J. Clin. Child Adolesc. Psychol. 39, 723-725.

Palmer, E., and Finger, S. (2001). An early description of ADHD (inattentive subtype): Dr. Alexander Crichton and "mental restlessness" (1798). Child Psychol. Psychiatry Rev. 6, 66-73.

Philippe, J., and Paul-Boncour, G. (1905). Les anomalies mentales chez les écoliers. Paris: Ancienne Librairie Germer Bailliére.

Polanczyk, G., De Lima, M. S., Horta, B. L., Biederman, J., and Rohde, L. A. (2007). The worldwide prevalence of ADHD: a systematic review and metaregression analysis. Am. J. Psychiatry 164, 942-948.

Rasmussen, P., and Gillberg, C. (2000). Natural outcome of ADHD with developmental coordination disorder at age 22 years: a controlled, longitudinal, community-based study. J. Am. Acad. Child Adolesc. Psychiatry 39, 1424-1431.

Rosler, M., Casas, M., Konofal, E., and Buitelaar, J. (2010). Attention deficit hyperactivity disorder in adults. World J. Biol. Psychiatry 11, 684-698.

Santosh, P. J., Taylor, E., Swanson, J., Wigal, T., Chuang, S., Davies, M., Greenhill, L., Arnold, L. E., Jensen, P., Vitiello, B., Elliott, G., Hinshaw, S., Hechtman, L., Abikoff, H., Pelham, W., Hoza, B., Molina, B., Wells, K., Epstein, J., and Posner, M. (2005). Refining the diagnoses of inattention and overactivity syndromes: a reanalysis of the multimodal treatment study of attention deficit hyperactivity disorder (ADHD) based on ICD-10 criteria for hyperkinetic disorder. Clin. Neurosci. Res. 5, 307-314.

Shaw, M., Caci, H., Hodgkins, P., Kahle, J., Callamaras, N., and Woods, A. (2011). Long-term outcomes of ADHD: global and regional study publication trends. Eur. Psychiatry 26(Suppl. 1), 578.
Stevens, J., Harman, J. S., and Kelleher, K. J. (2004). Ethnic and regional differences in primary care visits for attention-deficit hyperactivity disorder. J. Dev. Behav. Pediatr. 25, 318-325.

Still, G. (1902). Some abnormal psychical conditions in children. Lancet 1 , 1008-1010.

Stubbe, D. E. (2000). Attentiondeficit/hyperactivity disorder overview. Historical perspective, current controversies, and future directions. Child Adolesc. Psychiatr. Clin. N. Am. 9, 469-479, v.

Thome, J., and Jacobs, K. A. (2004). Attention deficit hyperactivity disorder (ADHD) in a 19th century children's book. Eur. Psychiatry 19, 303-306.

UN. (2011). United Nations Geoscheme. United Nations. Available: http:// unstats.un.org/unsd/methods/m49/ m49regin.htm [accessed August 27, 2011; Online].

WHO. (2010). "Mental and behavioural disorders," in International Statistical Classification of Diseases and Related Health Problems 10th Revision (ICD-10) Version for 2010, Chapt. V, Geneva: World Health Organization.

Wilcox, C. E., Washburn, R., and Patel, V. (2007). Seeking help for attention deficit hyperactivity disorder in developing countries: a study of parental explanatory models in Goa, India. Soc. Sci. Med. 64, 1600-1610.

Wood, D. R., Reimher, F. W., Wender P. H., and Johnson, G. E. (1976) Diagnosis and treatment of minimal brain dysfunction in adults: a preliminary report. Arch. Gen. Psychiatry 33, 1453-1460.

Young, S., and Amarasinghe, J. M. (2010). Practitioner review: nonpharmacological treatments for ADHD: a lifespan approach. J. Child. Psychol. Psychiatry 51, 116-133.

Young, S., Toone, B., and Tyson, C. (2003). Comorbidity and psychosocial profile of adults with attention deficit hyperactivity disorder. Pers. Individ. Dif. 35, 743-755.

Young, S. J., Adamou, M., Bolea, B. Gudjonsson, G., Muller, U., Pitts, M., Thome, J., and Asherson, P. (2011a). The identification and management of ADHD offenders within the criminal justice system: a consensus statement from the UK Adult ADHD Network and criminal justice agencies. BMC Psychiatry 11, 32. doi:10.1186/1471-244X-11-32

Young, S., Murphy, C. M., and Coghill, D. (2011b). Avoiding the "twilight zone": guidance and recommendations on ADHD and the transition between child and adult services. BMC Psychiatry 11, 174 doi:10.1186/1471-244X-11-174

Conflict of Interest Statement: Dr. Hodgkins is an employe of Shire Development Inc., owns Shire stock and has stock options. Dr. Arnold has received research funding or consulting fees from Astrazeneca, Biomarin, Curemark, Lilly, Novartis, Noven, Seaside Therapeutics, and Shire (nothing for contributing to this article). Dr. Shaw was an employee of Shire Pharmaceuticals, Ltd., when this analysis was conducted and when this manuscript was drafted. Dr. Caci has received consulting fees from Shire (nothing for contributing to this article). Dr. Kahle is owner of BPS International. BPS International received funding from Shire Development Inc., to perform this analysis and participate in writing this manuscript. Dr. Woods is a consultant for BPS International and has been a consultant for Shire Development, Inc. Dr. Young has received research funding or consulting fees from Janssen-Cilag, Eli-Lilly, Novatis, FlynnPharma, and Shire (nothing for contributing to this article). She was a member of the UK NICE Guideline Development Group for ADHD. Funded by Shire Development Inc., Wayne, PA, USA. An earlier version of this analysis was presented as a poster (Shaw et al., 2011).

Received: 16 November 2011; accepted: 29 December 2011; published online: 18 January 2012.

Citation: Hodgkins P, Arnold LE, Shaw $M$, Caci H, Kahle J, Woods AG and Young $S$ (2012) A systematic review of global publication trends regarding long-term outcomes of ADHD. Front. Psychiatry 2:84. doi: 10.3389/fpsyt.2011.00084

This article was submitted to Frontiers in Child and Neurodevelopmental Psychiatry, a specialty of Frontiers in Psychiatry. Copyright (c) 2012 Hodgkins, Arnold, Shaw, Caci, Kahle, Woods and Young. This is an open-access article distributed under the terms of the Creative Commons Attribution Non Commercial License, which permits non-commercial use, distribution, and reproduction in other forums, provided the original authors and source are credited. 


\section{APPENDIX}

\section{REFERENCES}

Abikoff, H., Hechtman, L., Klein, R. G., Gallagher, R., Fleiss, K., Etcovitch, J., Cousins, L., Greenfield, B., Martin, D., and Pollack, S. (2004). Social functioning in children with ADHD treated with longterm methylphenidate and multimodal psychosocial treatment. $J$. Am. Acad. Child Adolesc. Psychiatry 43, 820-829.

Achilles, G. M., Mclaughlin, M. J., and Croninger, R. G. (2007). Sociocultural correlates of disciplinary exclusion among students with emotional, behavioral, and learning disabilities in the SEELS National Dataset. J. Emot. Behav. Disord. 15, 33-45.

Advokat, C. D., Guidry, D., and Martino, L. (2008). Licit and illicit use of medications for attention-deficit hyperactivity disorder in undergraduate college students. J. Am. Coll. Health 56, 601-606.

Af Klinteberg, B., Andersson, T., Magnusson, D., and Stattin, H. (1993). Hyperactive behavior in childhood as related to subsequent alcohol problems and violent offending: a longitudinal study of male subjects. Pers. Individ. Dif. 15, 381-388.

Alterman, A. I., Petrarulo, E., Tarter, R., and Mcgowan, J. R. (1982). Hyperactivity and alcoholism: familial and behavioral correlates. Addict. Behav. 7, 413-421.

Alterman, A. I., Tarter, R. E., Baughman, T. G., Bober, B. A., and Fabian, S. A. (1985). Differentiation of alcoholics high and low in childhood hyperactivity. Drug Alcohol Depend. 15, 111-121.

Altfas, J. R. (2002). Prevalence of attention deficit/hyperactivity disorder among adults in obesity treatment. BMC Psychiatry 2, 9-16.

Andrade, R. C., Silva, V. A., and Assumpção, F. B. Jr. (2004). Preliminary data on the prevalence of psychiatric disorders in Brazilian male and female juvenile delinquents. Braz. J. Med. Biol. Res. 37, 1155-1160.

Antshel, K. M., Faraone, S. V., Maglione, K., Doyle, A., Fried, R., Seidman, L., and Biederman, J. (2008). Temporal stability of ADHD in the high-IQ population: results from the MGH Longitudinal Family Studies of ADHD. J. Am. Acad. Child Adolesc. Psychiatry 47, 817-825.

Antshel, K. M., Faraone, S. V., Maglione, K., Doyle, A., Fried, R., Seidman, L., and Biederman, J. (2009). Is adult attention deficit hyperactivity disorder a valid diagnosis in the presence of high IQ? Psychol. Med. 39, 1325-1335.

Auerbach, J. G., Gross-Tsur, V., Manor, O., and Shalev, R. S. (2008). Emotional and behavioral characteristics over a six-year period in youths with persistent and nonpersistent dyscalculia. J. Learn. Disabil. 41, 263-273.

August, G. J., and Holmes, C. S. (1984). Behavior and academic achievement in hyperactive subgroups and learning-disabled boys. a six-year follow-up. Am. J. Dis. Child 138, 1025-1029.

Aytaclar, S., Tarter, R. E., Kirisci, L., and Lu, S. (1999). Association between hyperactivity and executive cognitive functioning in childhood and substance use in early adolescence. J. Am. Acad. Child Adolesc. Psychiatry 38, 172-178.

Babinski, L. M., Hartsough, C. S., and Lambert, N. M. (1999). Childhood conduct problems, hyperactivityimpulsivity, and inattention as predictors of adult criminal activity. J. Child Psychol. Psychiatry 40, 347-355.

Bagwell, C. L., Molina, B. S. G., Pelham, W. E. Jr., and Hoza, B. (2001). Attention-deficit hyperactivity disorder and problems in peer relations: predictions from childhood to adolescence. J. Am. Acad. Child Adolesc. Psychiatry 40, 1285-1292.

Banks, S. R., Guyer, B. P., and Guyer, K. E. (1995). A study of medical students and physicians referred for learning disabilities. Ann. Dyslexia $45,233-245$.

Banks, T., Ninowski, J. E., Mash, E. J., and Semple, D. L. (2008). Parenting behavior and cognitions in a community sample of mothers with and without symptoms of attention-deficit/hyperactivity disorder. J. Child Fam. Stud. 17, 28-43.

Barbaresi, W. J., Katusic, S. K., Colligan, R. C., Weaver, A. L., and Jacobsen, S. J. (2007). Long-term school outcomes for children with attention-deficit/hyperactivity disorder: a population-based perspective. J. Dev. Behav. Pediatr. 28, 265-273.

Barkley, R. A., and Fischer, M. (2010). The unique contribution of emotional impulsiveness to impairment in major life activities in hyperactive children as adults. J. Am. Acad. Child Adolesc. Psychiatry 49, 503-513.

Barkley, R. A., Fischer, M., Edelbrock, C. S., and Smallish, L. (1990). The adolescent outcome of hyperactive children diagnosed by research criteria: I. an 8-year prospective followup study. J. Am. Acad. Child Adolesc. Psychiatry 29, 546-557.

Barkley, R. A., Fischer, M., Smallish, L., and Fletcher, K. (2003). Does the treatment of attentiondeficit/hyperactivity disorder with stimulants contribute to drug use/abuse? A 13-year prospective study. Pediatrics 111, 97-109.

Barkley, R. A., Fischer, M., Smallish, L., and Fletcher, K. (2004). Young adult follow-up of hyperactive children: antisocial activities and drug use. J. Child Psychol. Psychiatry 45, 195-211.

Barkley, R. A., Fischer, M., Smallish, L., and Fletcher, K. (2006). Young adult outcome of hyperactive children: adaptive functioning in major life activities. J. Am. Acad. Child Adolesc. Psychiatry 45, 192-202.

Barkley, R. A., Guevremont, D. C., Anastopoulos, A. D., Dupaul, G. J., and Shelton, T. L. (1993). Drivingrelated risks and outcomes of attention deficit hyperactivity disorder in adolescents and young adults: a 3to 5-year follow-up survey. Pediatrics 92, 212-218.

Barkley, R. A., Murphy, K. R., Dupaul, G. I., and Bush, T. (2002). Driving in young adults with attention deficit hyperactivity disorder: knowledge, performance, adverse outcomes, and the role of executive functioning. $J$. Int. Neuropsychol. Soc. 8, 655-672.

Biederman, J., Ball, S. W., Monuteaux, M. C., Mick, E., Spencer, T. J., Mccreary, M., Cote, M., and Faraone, S. V. (2008a). New insights into the comorbidity between ADHD and major depression in adolescent and young adult females. J. Am. Acad. Child Adolesc. Psychiatry 47, 426-434.

Biederman, J., Petty, C. R., Dolan, C., Hughes, S., Mick, E., Monuteaux, M. C., and Faraone, S. V. (2008b). The long-term longitudinal course of oppositional defiant disorder and conduct disorder in ADHD boys: findings from a controlled 10-year prospective longitudinal follow-up study. Psychol. Med. 38, 1027-1036.

Biederman, J., Petty, C. R., Fried, R., Kaiser, R., Dolan, C. R., Schoenfeld, S., Doyle, A. E., Seidman, L. J., and Faraone, S. V. (2008c). Educational and occupational underattainment in adults with attentiondeficit/hyperactivity disorder: a controlled study. J. Clin. Psychiatry 69, 1217-1222.
Biederman, J., Faraone, S., Milberger, S., Guite, J., Mick, E., Chen, L., Mennin, D., Marrs, A., Ouellette, C., Moore, P., Spencer, T., Norman, D., Wilens, T., Kraus, I., and Perrin, J. (1996). A prospective 4-year followup study of attention-deficit hyperactivity and related disorders. Arch. Gen. Psychiatry 53, 437-446.

Biederman, J., and Faraone, S. V. (2006). The effects of attentiondeficit/hyperactivity disorder on employment and household income. MedGenMed. 8, 12.

Biederman, J., Faraone, S. V., Spencer, T., Wilens, T., Mick, E., and Lapey, K. A. (1994). Gender differences in a sample of adults with attention deficit hyperactivity disorder. Psychiatry Res. 53, 13-29.

Biederman, J., Faraone, S. V., Spencer, T. J., Mick, E., Monuteaux, M. C., and Aleardi, M. (2006a). Functional impairments in adults with selfreports of diagnosed ADHD: a controlled study of 1001 adults in the community. J. Clin. Psychiatry 67, 524-540.

Biederman, J., Monuteaux, M. C., Mick, E., Spencer, T., Wilens, T. E., Klein, K. L., Price, J. E., and Faraone, S. V. (2006b). Psychopathology in females with attention-deficit/hyperactivity disorder: a controlled, five-year prospective study. Biol. Psychiatry 60, 1098-1105.

Biederman, J., Monuteaux, M. C., Mick, E., Wilens, T. E., Fontanella, J. A., Poetzl, K. M., Kirk, T., Masse, J., and Faraone, S. V. (2006c). Is cigarette smoking a gateway to alcohol and illicit drug use disorders? A study of youths with and without attention deficit hyperactivity disorder. Biol. Psychiatry 59, 258-264.

Biederman, J., Petty, C., Fried, R., Fontanella, J., Doyle, A. E., Seidman, L. J., and Faraone, S. V. (2006d). Impact of psychometrically defined deficits of executive functioning in adults with attention deficit hyperactivity disorder. Am. J. Psychiatry $163,1730-1738$.

Biederman, J., Faraone, S. V., Taylor, A., Sienna, M., Williamson, S., and Fine, C. (1998a). Diagnostic continuity between child and adolescent ADHD: findings from a longitudinal clinical sample. J. Am. Acad. Child Adolesc. Psychiatry 37, 305-313.

Biederman, J., Wilens, T. E., Mick, E., Faraone, S. V., and Spencer, T. (1998b). Does attention-deficit hyperactivity disorder impact the developmental course of drug and 
alcohol abuse and dependence? Biol. Psychiatry 44, 269-273.

Biederman, J., Fried, R., Monuteaux, M. C., Reimer, B., Coughlin, J. F., Surman, C. B., Aleardi, M., Dougherty, M., Schoenfeld, S., Spencer, T. J., and Faraone, S. V. (2007). A laboratory driving simulation for assessment of driving behavior in adults with ADHD: a controlled study. Ann. Gen. Psychiatry 6, 4-10.

Biederman, J., Mick, E., Fried, R., Aleardi, M., Potter, A., and Herzig, K. (2005). A simulated workplace experience for nonmedicated adults with and without ADHD. Psychiatr. Serv. 56, 1617-1620.

Biederman, J., Monuteaux, M. C., Doyle, A. E., Seidman, L. J., Wilens, T. E., Ferrero, F., Morgan, C. L., and Faraone, S. V. (2004). Impact of executive function deficits and attention-deficit/hyperactivity disorder (ADHD) on academic outcomes in children. J. Consult. Clin. Psychol. 72, 757-766.

Biederman, J., Monuteaux, M. C., Spencer, T., Wilens, T. E., and Faraone, S. V. (2009a). Do stimulants protect against psychiatric disorders in youth with ADHD? A 10year follow-up study. Pediatrics 124, 71-78.

Biederman, J., Petty, C. R., Ball, S. W., Fried, R., Doyle, A. E., Cohen, D., Henderson, C., and Faraone, S. V. (2009b). Are cognitive deficits in attention deficit/hyperactivity disorder related to the course of the disorder? A prospective controlled follow-up study of grown up boys with persistent and remitting course. Psychiatry Res. 170, 177-182.

Biederman, J., Petty, C. R., Monuteaux, M. C., Fried, R., Byrne, D., Mirto, T., Spencer, T., Wilens, T. E., and Faraone, S. V. (2010). Adult psychiatric outcomes of girls with attention deficit hyperactivity disorder: 11-year follow-up in a longitudinal case-control study. Am. J. Psychiatry $167,409-417$.

Biederman, J., Wilens, T., Mick, E., Faraone, S. V., Weber, W., Curtis, S., Thornell, A., Pfister, K., Jetton, J. G., and Soriano, J. (1997). Is ADHD a risk factor for psychoactive substance use disorders? Findings from a four-year prospective follow-up study. J. Am. Acad. Child Adolesc. Psychiatry 36, 21-29.

Biederman, J., Wilens, T., Mick, E., Milberger, S., Spencer, T., and Faraone, S. V. (1995). Psychoactive substance use disorders in adults with attention deficit hyperactivity disorder (ADHD): effects of ADHD and psychiatric comorbidity. Am. J. Psychiatry 152, 1652-1658.

Bird, H. R., Shrout, P. E., Duarte, C. S., Shen, S., Bauermeister, J. J., and Canino, G. (2008). Longitudinal mental health service and medication use for ADHD among Puerto Rican youth in two contexts. J. Am. Acad. Child Adolesc. Psychiatry 47, 879-889.

Blase, S. L., Gilbert, A. N., Anastopoulos, A. D., Costello, E. J., Hoyle, R. H., Swartzwelder, H. S., and Rabiner, D. L. (2009). Self-reported ADHD and adjustment in college: crosssectional and longitudinal findings. J. Atten. Disord. 13, 297-309.

Breslin, F. C., and Pole, J. D. (2009). Work injury risk among young people with learning disabilities and attention-deficit/hyperactivity disorder in Canada. Am. J. Public Health 99, 1423-1430.

Breyer, J. L., Botzet, A. M., Winters, K. C., Stinchfield, R. D., August, G., and Realmuto, G. (2009). Young adult gambling behaviors and their relationship with the persistence of ADHD. J. Gambl. Stud. 25, 227-238.

Brook, J. S., Duan, T., Zhang, C., Cohen, P. R., and Brook, D. W. (2008). The association between attention deficit hyperactivity disorder in adolescence and smoking in adulthood. Am. J. Addict. 17, 54-59.

Brook, U., and Boaz, M. (2005). Attention deficit and hyperactivity disorder/learning disabilities (ADHD/LD): parental characterization and perception. Patient Educ Couns. 57, 96-100.

Brown, J. M., and Nixon, S. J. (1997). Gender and drug differences in antisocial personality disorder. J. Clin. Psychol. 53, 301-305.

Burd, L., Klug, M., Coumbe, M., and Kerbeshian, J. (2003a). The Attention-deficit hyperactivity disorder paradox: 2. Phenotypic variability in prevalence and cost of comorbidity. J. Child Neurol. 18, 653-660.

Burd, L., Klug, M. G., Coumbe, M. J., and Kerbeshian, J. (2003b). Children and adolescents with attention deficit-hyperactivity disorder: 1. Prevalence and cost of care. J. Child Neurol. 18, 555-561.

Burke, J. D., Loeber, R., and Lahey, B. B. (2001). Which aspects of ADHD are associated with tobacco use in early adolescence? J. Child Psychol. Psychiatry 42, 493-502.

Canu, W. H., and Carlson, C. L. (2003). Differences in heterosocial behavior and outcomes of ADHDsymptomatic subtypes in a college sample. J. Atten. Disord. 6, 123-133.
Canu, W. H., and Carlson, C. L. (2007) Rejection sensitivity and social outcomes of young adult men with ADHD. J. Atten. Disord. 10, 261-275.

Carlton, P. L., and Manowitz, P. (1992). Behavioral restraint and symptoms of attention deficit disorder in alcoholics and pathological gamblers. Neuropsychobiology 25, 44-48.

Carroll, K. M., and Rounsaville, B. J. (1993). History and significance of childhood attention deficit disorder in treatment-seeking cocaine abusers. Compr. Psychiatry 34 75-82.

Charles, L., and Schain, R. (1981). A four-year follow-up study of the effects of methylphenidate on the behavior and academic achievement of hyperactive children. J. Abnorm. Child Psychol. 9, 495-505.

Chen, A. Y., Kim, S. E., Houtrow, A. J., and Newacheck, P. W. (2010). Prevalence of obesity among children with chronic conditions. Obesity 18, 210-213.

Chilcoat, H. D., and Breslau, N. (1999). Pathways from ADHD to early drug use. J. Am. Acad. Child Adolesc. Psychiatry 38, 1347-1354.

Cho, S. C., Kim, J. W., Choi, H. J., Kim, B. N., Shin, M. S., Lee, J. H. and Kim, E. H. (2008). Associations between symptoms of attention deficit hyperactivity disorder, depression, and suicide in Korean female adolescents. Depress Anxiety 25, E142-E146.

Chronis-Tuscano, A., Molina, B. S. G. Pelham, W. E., Applegate, B., Dahlke, A., Overmyer, M., and Lahey, B. B. (2010). Very early predictors of adolescent depression and suicide attempts in children with attentiondeficit/hyperactivity disorder. Arch. Gen. Psychiatry 67, 1044-1051.

Claude, D., and Firestone, P. (1995). The development of ADHD boys: a 12year follow-up. Can. J. Behav. Sci. 27, 226-249.

Clure, C., Brady, K. T., Saladin, M. E., Johnson, D., Waid, R., and Rittenbury, M. (1999). Attention deficit/hyperactivity disorder and substance use: symptoms pattern and drug choice. Am. J. Drug Alcohol Abuse 25, 441-448.

Covey, L. S., Manubay, J., Jiang, H., Nortick, M., and Palumbo, D. (2008). Smoking cessation and inattention or hyperactivity/impulsivity: a post hoc analysis. Nicotine Tob. Res. 10, 1717-1725.

Cox, D. J., Merkel, R. L., Kovatchev, B., and Seward, R. (2000). Effect of stimulant medication on driving performance of young adults with attention-deficit hyperactivity disorder: a preliminary double-blind placebo controlled trial. J. Nerv. Ment. Dis. 188, 230-234.

Creemers, H. E., Van Lier, P. a. C., Vollebergh, W. a. M., Ormel, J., Verhulst, F. C., and Huizink, A. C. (2009). Predicting onset of cannabis use in early adolescence: the interrelation between high-intensity pleasure and disruptive behavior. The TRAILS Study. J. Stud. Alcohol Drugs $70,850-858$.

Crowley, T. J., Mikulich, S. K., Macdonald, M., Young, S. E., and Zerbe, G. O. (1998). Substance-dependent, conduct-disordered adolescent males: severity of diagnosis predicts 2-year outcome. Drug Alcohol Depend. 49, 225-237.

Curtin, C., Bandini, L. G., Perrin, E. C., Tybor, D. J., and Must, A. (2005). Prevalence of overweight in children and adolescents with attention deficit hyperactivity disorder and autism spectrum disorders: a chart review. BMC Pediatr. 5, 48. doi:10.1186/1471-2431-5-48

Danckaerts, M., Heptinstall, E., Chadwick, O., and Taylor, E. (2000) A natural history of hyperactivity and conduct problems: self-reported outcome. Eur. Child Adolesc. Psychiatry 9, 26-38.

Davis, C., Levitan, R. D., Smith, M., Tweed, S., and Curtis, C. (2006) Associations among overeating, overweight, and attention deficit/hyperactivity disorder: a structural equation modelling approach. Eat. Behav. 7, 266-274.

De Graaf, R., Kessler, R. C., Fayyad, J., Ten Have, M., Alonso, J., Angermeyer, M., Borges, G., Demyttenaere, K., Gasquet, I., De Girolamo, G., Haro, J. M., Jin, R., Karam, E. G., Ormel, J., and Posada-Villa, J. (2008). The prevalence and effects of adult attention-deficit/hyperactivity disorder (ADHD) on the performance of workers: results from the WHO World Mental Health Survey Initiative. Occup. Environ. Med. 65, 835-842.

De Ridder, A., and De Graeve, D. (2006). Healthcare use, social burden and costs of children with and without ADHD in Flanders, Belgium. Clin. Drug Investig. 26, 75-90.

Demilio, L. (1989). Psychiatric syndromes in adolescent substance abusers. Am. J. Psychiatry 146, 1212-1214.

Diamantopoulou, S., Rydell, A.-M., Thorell, L. B., and Bohlin, G. (2007) Impact of executive functioning and symptoms of attention deficit hyperactivity disorder on children's peer 
relations and school performance. Dev. Neuropsychol. 32, 521-542.

Dobkin, P. L., Tremblay, R. E., Mâsse, L. C., and Vitaro, F. (1995). Individual and peer characteristics in predicting boys' early onset of substance abuse: a seven-year longitudinal study. Child Dev. 66, 1198-1214.

Downey, K. K., Pomerleau, C. S., and Pomerleau, O. F. (1996). Personality differences related to smoking and adult attention deficit hyperactivity disorder. J. Subst. Abuse 8, 129-135.

Downey, K. K., Stelson, F. W., Pomerleau, O. F., and Giordani, B. (1997). Adult attention deficit hyperactivity disorder: psychological test profiles in a clinical population. J. Nerv. Ment. Dis. 185, 32-38.

Dupaul, G. J., Ervin, R. A., Hook, C. L., and Mcgoey, K. E. (1998). Peer tutoring for children with attention deficit hyperactivity disorder: effects on classroom behavior and academic performance. J. Appl. Behav. Anal. 31, 579-592.

Eakin, L., Minde, K., Hechtman, L., Ochs, E., Krane, E., Bouffard, R., Greenfield, B., and Looper, K. (2004). The marital and family functioning of adults with ADHD and their spouses. J. Atten. Disord. 8, $1-10$.

Edbom, T., Granlund, M., Lichtenstein, P., and Larsson, J.-O. (2008). ADHD symptoms related to profiles of selfesteem in a longitudinal study of twins: a person-oriented approach. J. Child Adolesc. Psychiatr. Nurs. 21, 228-237.

Edbom, T., Lichtenstein, P., Granlund, M., and Larsson, J.-O. (2006). Long-term relationships between symptoms of attention deficit hyperactivity disorder and selfesteem in a prospective longitudinal study of twins. Acta Paediatr. 95, 650-657.

Eklund, J. M., and Klinteberg, B. A. F. (2003). Childhood behaviour as related to subsequent drinking offences and violent offending: a prospective study of 11- to 14year-old youths into their fourth decade. Crim. Behav. Ment. Health 13, 294-309.

Elander, J., Simonoff, E., Pickles, A., Holmshaw, J., and Rutter, M. (2000). A longitudinal study of adolescent and adult conviction rates among children referred to psychiatric services for behavioural or emotional problems. Crim. Behav. Ment. Health 10, 40-59.

Elkins, I. J., Mcgue, M., and Iacono, W. G. (2007). Prospective effects of attention-deficit/hyperactivity disorder, conduct disorder, and sex on adolescent substance use and abuse. Arch. Gen. Psychiatry 64, 1145-1152.

Ercan, E. S., Coskunol, H., Varan, A., and Toksöz, K. (2003). Childhood attention deficit/hyperactivity disorder and alcohol dependence: a 1year follow-up. Alcohol Alcohol. 38, 352-356.

Ernst, M., Luckenbaugh, D. A., Moolchan, E. T., Leff, M. K., Allen, R., Eshel, N., London, E. D., and Kimes, A. (2006). Behavioral predictors of substance-use initiation in adolescents with and without attention-deficit/hyperactivity disorder. Pediatrics 117, 2030-2039.

Evans, S. W., Serpell, Z. N., Schultz, B. K., and Pastor, D. A. (2007). Cumulative benefits of secondary school-based treatment of students with attention deficit hyperactivity disorder. Sch. Psychol. Rev. 36, 256-273.

Eyre, S. L., Rounsaville, B. J., and Kleber, H. D. (1982). History of childhood hyperactivity in a clinic population of opiate addicts. J. Nerv. Ment. Dis. $170,522-529$.

Faraone, S. V., Biederman, J., Monuteaux, M. C., Doyle, A. E., and Seidman, L. J. (2001). A psychometric measure of learning disability predicts educational failure four years later in boys with attention-deficit/hyperactivity disorder. J. Atten. Disord. 4, 220-230.

Faraone, S. V., Wilens, T. E., Petty, C., Antshel, K., Spencer, T., and Biederman, J. (2007). Substance use among ADHD adults: implications of late onset and subthreshold diagnoses. Am. J. Addict. 16, 24-34.

Farrington, D. P., Ttofi, M. M., and Coid, J. W. (2009). Development of adolescence-limited, late-onset, and persistent offenders from age 8 to age 48. Aggress. Behav. 35, 150-163.

Fergusson, D. M., Boden, J. M., and Horwood, L. J. (2010). Classification of behavior disorders in adolescence: scaling methods, predictive validity, and gender differences. J. Abnorm. Psychol. 119, 699-712.

Fergusson, D. M., and Horwood, L. J. (1992). Attention deficit and reading achievement. J. Child Psychol. Psychiatry 33, 375-385.

Fergusson, D. M., and Horwood, L. J. (1995). Predictive validity of categorically and dimensionally scored measures of disruptive childhood behaviors. J. Am. Acad. Child Adolesc. Psychiatry 34, 477-485; discussion 485-477.

Fergusson, D. M., Horwood, L. J., and Lynskey, M. T. (1993). The effects of conduct disorder and attention deficit in middle childhood on offending and scholastic ability at age 13. J. Child Psychol. Psychiatry 34, 899-916.

Firestone, P., Crowe, D., Goodman, J. T., and Mcgrath, P. (1986). Vicissitudes of follow-up studies: differential effects of parent training and stimulant medication with hyperactives. Am. J. Orthopsychiatry 56, 184-194.

Fischer, M., and Barkley, R. A. (2003) Childhood stimulant treatment and risk for later substance abuse. J. Clin. Psychiatry 64, 19-23.

Fischer, M., Barkley, R. A., Edelbrock, C. S., and Smallish, L. (1990). The adolescent outcome of hyperactive children diagnosed by research criteria: II. Academic, attentional, and neuropsychological status. J. Consult. Clin. Psychol. 58, 580-588.

Fischer, M., Barkley, R. A., Fletcher, K. E., and Smallish, L. (1993a). The adolescent outcome of hyperactive children: predictors of psychiatric, academic, social, and emotional adjustment. J. Am. Acad. Child Adolesc. Psychiatry 32, 324-332.

Fischer, M., Barkley, R. A., Fletcher, K. E., and Smallish, L. (1993b). The stability of dimensions of behavior in ADHD and normal children over an 8-year followup. J. Abnorm. Child Psychol. 21, 315-337.

Fischer, M., Barkley, R. A., Smallish, L., and Fletcher, K. (2007). Hyperactive children as young adults: driving abilities, safe driving behavior, and adverse driving outcomes. Accid. Anal. Prev. 39, 94-105.

Fleming, J. P., Levy, L. D., and Levitan, R. D. (2005). Symptoms of attention deficit hyperactivity disorder in severely obese women. Eat. Weight Disord. 10, e10-e13.

Flory, K., Molina, B. S. G., Pelham, W. E. Jr., Gnagy, E., and Smith, B. (2006). Childhood ADHD predicts risky sexual behavior in young adulthood. J. Am. Acad. Child Adolesc. Psychiatry 35, 571-577.

Ford, T., Fowler, T., Langley, K., Whittinger, N., and Thapar, A. (2008). Five years on: public sector service use related to mental health in young people with ADHD or hyperkinetic disorder five years after diagnosis. Child Adolesc. Ment. Health 13 , 122-129.

Forehand, R., Wierson, M., Frame, C., Kempton, T., and Armistead, L. (1991). Juvenile delinquency entry and persistence: do attention problems contribute to conduct problems? J. Behav. Ther. Exp. Psychiatry 22, 261-264.
Frankel, F., Cantwell, D. P., Myatt, R., and Feinberg, D. T. (1999). Do stimulants improve self-esteem in children with ADHD and peer problems? J. Child Adolesc. Psychopharmacol. 9, 185-194.

Frankel, F., Myatt, R., Cantwell, D. P., and Feinberg, D. T. (1997). Parent-assisted transfer of children's social skills training: effects on children with and without attentiondeficit hyperactivity disorder. J. Am . Acad. Child Adolesc. Psychiatry 36, 1056-1064.

Fried, R., Petty, C. R., Surman, C. B., Reimer, B., Aleardi, M., Martin, J. M., Coughlin, J. F., and Biederman, J. (2006). Characterizing impaired driving in adults with attentiondeficit/hyperactivity disorder: a controlled study. J. Clin. Psychiatry 67, 567-574.

Galéra, C., Bouvard, M. P., Encrenaz, G., Messiah, A., and Fombonne, E. (2008a). Hyperactivity-inattention symptoms in childhood and suicidal behaviors in adolescence: the Youth Gazel Cohort. Acta Psychiatr. Scand. 118 480-489.

Galéra, C., Bouvard, M. P., Messiah, A., and Fombonne, E. (2008b). Hyperactivity-inattention symptoms in childhood and substance use in adolescence: the youth gazel cohort. Drug Alcohol Depend. 94, 30-37.

Galéra, C., Bouvard, M. P., Melchior M., Chastang, J. F., Lagarde, E., Michel, G., Encrenaz, G., Messiah, A., and Fombonne, E. (2010a). Disruptive symptoms in childhood and adolescence and early initiation of tobacco and cannabis use: the Gazel Youth study. Eur. Psychiatry 25, 402-408.

Galéra, C., Messiah, A., Melchior, M., Chastang, J.-F., Encrenaz, G. Lagarde, E., Michel, G., Bouvard, M.-P., and Fombonne, E. (2010b). Disruptive behaviors and early sexual intercourse: the Gazel Youth Study. Psychiatry Res. 177, 361-363.

Gillberg, I. C., and Gillberg, C. (1988). Generalized hyperkinesis: follow-up study from age 7 to 13 years. J. Am. Acad. Child Adolesc. Psychiatry 27, 55-59.

Gillberg, I. C., and Gillberg, C. (1989). Children with preschool minor neurodevelopmental disorders: IV. Behaviour and school achievement at age 13. Dev. Med. Child Neurol. $31,3-13$.

Gillberg, I. C., Gillberg, C., and Rasmussen, P. (1983). Three-year follow-up at age 10 of children with 
minor neurodevelopmental disorders: II. School achievement problems. Dev. Med. Child Neurol. 25, 566-573.

Giotakos, O., Markianos, M., and Vaidakis, N. (2005). Aggression, impulsivity, and plasma sex hormone levels in a group of rapists, in relation to their history of childhood attention-deficit/hyperactivity disorder symptoms. J. Forens. Psychiatry Psychol. 16, 423-433.

Gittelman, R., Mannuzza, S., Shenker, R., and Bonagura, N. (1985). Hyperactive boys almost grown up. I. Psychiatric status. Arch. Gen. Psychiatry 42, 937-947.

Glenn, S. W., and Parsons, O. A. (1991). Prediction of resumption of drinking in posttreatment alcoholics. Int. J. Addict. 26, 237-254.

Goksøyr, P. K., and Nøttestad, J. A. (2008). The burden of untreated ADHD among adults: the role of stimulant medication. Addict. Behav. 33, 342-346.

Goldston, D. B., Walsh, A., Arnold,E. M., Reboussin, B., Daniel, S. S., Erkanli, A., Nutter, D., Hickman, E., Palmes, G., Snider, E., and Wood, F. B. (2007). Reading problems, psychiatric disorders, and functional impairment from mid- to late adolescence. J. Am. Acad. Child Adolesc. Psychiatry 46, 25-32.

Gordon, J. A., and Moore, P. M. (2005). ADHD among incarcerated youth: an investigation on the congruency with ADHD prevalence and correlates among the general population. Am. J. Crim. Justice 30, 87-97.

Gosden, N. P., Kramp, P., Gabrielsen, G., and Sestoft, D. (2003). Prevalence of mental disorders among 15-17-yearold male adolescent remand prisoners in Denmark. Acta Psychiatr. Scand. 107, 102-110.

Greene, R. W., Biederman, J., Faraone, S. V., Sienna, M., and Garcia-Jetton, J. (1997). Adolescent outcome of boys with attention-deficit/hyperactivity disorder and social disability: results from a 4-year longitudinal follow-up study. J. Consult. Clin. Psychol. 65, 758-767.

Greene, R. W., Biederman, J., Faraone, S. V., Wilens, T. E., Mick, E., and Blier, H. K. (1999). Further validation of social impairment as a predictor of substance use disorders: findings from a sample of siblings of boys with and without ADHD. J. Clin. Child Psychol. 28, 349-354.

Greenfield, B., Hechtman, L., and Weiss, G. (1988). Two subgroups of hyperactives as adults: correlations of outcome. Can. J. Psychiatry 33, 505-508.
Gresham, F. M., Macmillan, D. L., Bocian, K. M., Ward, S. L., and Forness, S. R. (1998). Comorbidity of hyperactivity-impulsivityinattention and conduct problems: risk factors in social, affective, and academic domains. J. Abnorm. Child Psychol. 26, 393-406.

Grizenko, N. (1997). Outcome of multimodal day treatment for children with severe behavior problems: a five-year follow-up. J. Am. Acad. Child Adolesc. Psychiatry 36, 989-997.

Gropper, R. J., and Tannock, R. (2009). A pilot study of working memory and academic achievement in college students with ADHD. J. Atten. Disord. 12, 574-581.

Grskovic, J. A., and Zentall, S. S. (2010). Understanding ADHD in girls: identification and social characteristics. Int. J. Spec. Educ. 25, 171-184.

Gunter, T. D., Arndt, S., RigginsCaspers, K., Wenman, G., and Cadoret, R. J. (2006). Adult outcomes of attention deficit hyperactivity disorder and conduct disorder: are the risks independent or additive? Ann. Clin. Psychiatry 18, 233-237.

Halmøy, A., Fasmer, O. B., Gillberg, C., and Haavik, J. (2009). Occupational outcome in adult ADHD: impact of symptom profile, comorbid psychiatric problems, and treatment: a cross-sectional study of 414 clinically diagnosed adult ADHD patients. J. Atten. Disord. 13, 175-187.

Hansen, C., Weiss, D., and Last, C. G. (1999). ADHD boys in young adulthood: psychosocial adjustment. J. Am. Acad. Child Adolesc. Psychiatry $38,165-171$.

Hariharan, S., and Pomerantz, W. (2008). Correlation between hospitalization for pharmaceutical ingestion and attention deficit disorder in children aged 5 to 9 years old. Clin. Pediatr. (Phila.) 47, 15-20.

Hazell, P. L., Carr, V., Lewin, T. J., and Sly, K. (2003). Manic symptoms in young males with ADHD predict functioning but not diagnosis after 6 years. J. Am. Acad. Child Adolesc. Psychiatry 42, 552-560.

Hechtman, L., Abikoff, H., Klein, R. G., Weiss, G., Respitz, C., Kouri, J., Blum, C., Greenfield, B., Etcovitch, J., Fleiss, K., and Pollack, S. (2004). Academic achievement and emotional status of children with ADHD treated with longterm methylphenidate and multimodal psychosocial treatment. J. Am. Acad. Child Adolesc. Psychiatry $43,812-819$.
Hechtman, L., and Weiss, G. (1986). Controlled prospective fifteen year follow-up of hyperactives as adults: non-medical drug and alcohol use and anti-social behaviour. Can. J. Psychiatry 31, 557-567.

Hechtman, L., Weiss, G., and Perlman, T. (1984a). Hyperactives as young adults: past and current substance abuse and antisocial behavior. Am. J. Orthopsychiatry 54 415-425.

Hechtman, L., Weiss, G., and Perlman, T. (1984b). Young adult outcome of hyperactive children who received long-term stimulant treatment. J. Am. Acad. Child Psychiatry 23, 261-269.

Heiligenstein, E., Guenther, G., Levy, A., Savino, F., and Fulwiler, J. (1999). Psychological and academic functioning in college students with attention deficit hyperactivity disorder. J. Am. Coll. Health 47, 181-185.

Heinicke, C. M., and Ramsey-Klee, D. M. (1986). Outcome of child psychotherapy as a function of frequency of session. J. Am. Acad. Child Psychiatry 25, 247-253.

Hesse, M. (2010). Course of selfreported symptoms of attention deficit and hyperactivity in substance abusers during early treatment. Addict. Behav. 35, 504-506.

Hesselbrock, V. M., Stabenau, J. R., and Hesselbrock, M. N. (1985). Minimal brain dysfunction and neuropsychological test performance in offspring of alcoholics. Recent Dev. Alcohol. 3 , 65-82.

Hinshaw, S. P., Owens, E. B., Sami, N., and Fargeon, S. (2006). Prospective follow-up of girls with attentiondeficit/hyperactivity disorder into adolescence: evidence for continuing cross-domain impairment. J. Consult. Clin. Psychol. 74, 489-499.

Horner, B. R., and Scheibe, K. E. (1997). Prevalence and implications of attention-deficit hyperactivity disorder among adolescents in treatment for substance abuse. J. Am Acad. Child Adolesc. Psychiatry 36, 30-36.

Howell, D. C., Huessy, H. R., and Hassuk, B. (1985). Fifteen-year followup of a behavioral history of attention deficit disorder. Pediatrics 76, 185-190.

Huizink, A. C., Van Lier, P. C., and Crijnen, A. M. (2009). Attention deficit hyperactivity disorder symptoms mediate early-onset smoking. Eur. Addict. Res. 15, 1-9.

Huss, M., Poustka, F., Lehmkuhl, G., and Lehmkuhl, U. (2008). No increase in long-term risk for nicotine use disorders after treatment with methylphenidate in children with attention-deficit/hyperactivity disorder (ADHD): evidence from a non-randomised retrospective study. J. Neural Transm. 115, 335-339.

Izutsu, T., Shimotsu, S., Matsumoto, T., Okada, T., Kikuchi, A., Kojimoto, M., Noguchi, H., and Yoshikawa, K. (2006). Deliberate self-harm and childhood hyperactivity in junior high school students. Eur. Child Adolesc. Psychiatry 15, 172-176.

Jensen, P. S., Arnold, L. E., Swanson, J. M., Vitiello, B., Abikoff, H. B., Greenhill, L. L., Hechtman, L., Hinshaw, S. P., Pelham, W. E., Wells, K. C., Conners, C. K., Elliott, G. R., Epstein, J. N., Hoza, B., March, J. S., Molina, B. S. G., Newcorn, J. H., Severe, J. B., Wigal, T., Gibbons, R. D., and Hur, K. (2007). 3-Year followup of the NIMH MTA study. J. Am. Acad. Child Adolesc. Psychiatry 46, 989-1002.

Jester, J. M., Nigg, J. T., Buu, A., Puttler, L. I., Glass, J. M., Heitzeg, M. M., Fitzgerald, H. E., and Zucker, R. A. (2008). Trajectories of childhood aggression and inattention/hyperactivity: differential effects on substance abuse in adolescence. J. Am. Acad. Child Adolesc. Psychiatry 47, 1158.

Johansson, P., Kerr, M., and Andershed, H. (2005). Linking adult psychopathy with childhood hyperactivityimpulsivity-attention problems and conduct problems through retrospective self-reports. J. Pers. Disord. 19, 94-101.

Johnson, M. C., and Kercher, G. A. (2007). ADHD, strain, and criminal behavior: a test of general strain theory. Deviant Behav. 28, 131-152.

Johnston, C., and Pelham, W. E. (1986). Teacher ratings predict peer ratings of aggression at 3-year follow-up in boys with attention deficit disorder with hyperactivity. J. Consult. Clin. Psychol. 54, 571-572.

Jones, D. E., Foster, E. M., and Group, C. P. P. R. (2009). Service use patterns for adolescents with ADHD and comorbid conduct disorder. J. Behav. Health Serv. Res. 36 , 436-449.

Jorgensen, S., Fichten, C. S., Havel, A., Lamb, D., James, C., Barile, M., and Network, A. R. (2003). Students with and without disabilities at Dawson college graduate at the same rate. $J$. Vocat. Spec. Needs Educ. 25, 44-46.

Kafka, M. P., and Hennen, J. (2002). A DSM-IV axis I comorbidity study of males $(n(120)$ with paraphilias 
and paraphilia-related disorders. Sex Abuse 14, 349-366.

Kalyva, E. (2007). Prevalence and influences on self-reported smoking among adolescents with mild learning disabilities, attention deficit hyperactivity disorder, and their typically developing peers. J. Intellect. Disabil. 11, 267-279.

Katusic, S. K., Barbaresi, W. J., Colligan, R. C., Weaver, A. L., Leibson, C. L., and Jacobsen, S. J. (2005). Psychostimulant treatment and risk for substance abuse among young adults with a history of attention-deficit/hyperactivity disorder: a population-based, birth cohort study. J. Child Adolesc. Psychopharmacol. 15, 764-776.

Kaya, A., Taner, Y., Guclu, B., Taner, E., Kaya, Y., Bahcivan, H. G., and Benli, I. T. (2008). Trauma and adult attention deficit hyperactivity disorder. $J$. Int. Med. Res. 36, 9-16.

Kelly, P. C., Cohen, M. L., Walker, W. O., Caskey, O. L., and Atkinson, A. W. (1989). Self-esteem in children medically managed for attention deficit disorder. Pediatrics 83, 211-217.

Kessler, R. C., Adler, L., Ames, M., Barkley, R. A., Birnbaum, H., Greenberg, P., Johnston, J. A., Spencer, T., and Üstün, T. B. (2005). The prevalence and effects of adult attention deficit/hyperactivity disorder on work performance in a nationally representative sample of workers. J. Occup. Environ. Med. 47, 565-572.

King, V. L., Brooner, R. K., Kidorf, M. S., Stoller, K. B., and Mirsky, A. F. (1999). Attention deficit hyperactivity disorder and treatment outcome in opioid abusers entering treatment. J. Nerv. Ment. Dis. 187, 487-495.

Knop, J., Penick, E. C., Nickel, E. J., Mortensen, E. L., Sullivan, M. A., Murtaza, S., Jensen, P., Manzardo, A. M., and Gabrielli, W. F. Jr. (2009). Childhood ADHD and conduct disorder as independent predictors of male alcohol dependence at age 40. J. Stud. Alcohol Drugs 70, 169-177.

Ko, C.-H., Yen, J.-Y., Chen, C.-S., Yeh, Y.C., and Yen, C.-F. (2009). Predictive values of psychiatric symptoms for internet addiction in adolescents: a 2-year prospective study. Arch. Pediatr. Adolesc. Med. 163, 937-943.

Kolpe, M., and Carlson, G. A. (2007). Influence of attentiondeficit/hyperactivity disorder symptoms on methadone treatment outcome. Am. J. Addict. 16, 46-48.

Krauss, M. R., Russell, R. K., Powers, T. E., and Li, Y. (2006).
Accession standards for attentiondeficit/hyperactivity disorder: a survival analysis of military recruits, 1995-2000. Mil. Med. 171, 99-102.

Laasonen, M., Lehtinen, M., Leppämäki, S., Tani, P., and Hokkanen, L. (2010). Project DyAdd: phonological processing, reading, spelling, and arithmetic in adults with dyslexia or ADHD. J. Learn. Disabil. 43, 3-14.

Lahey, B. B., and Willcutt, E. G. (2010). Predictive validity of a continuous alternative to nominal subtypes of attention-deficit/hyperactivity disorder for DSM-V. J. Clin. Child Adolesc. Psychol. 39, 761-775.

Lam, A. K. S., and Ho, T. P. (2010). Early adolescent outcome of attentiondeficit hyperactivity disorder in a Chinese population: 5-year followup study. Hong Kong Med. J. 16, 257-264.

Lam, L. T., Yang, L., Zheng, Y., Ruan, C., and Lei, Z. (2006). Attention deficit and hyperactivity disorder tendency and unintentional injury among adolescents in China. Accid. Anal. Prev. 38, 1176-1182.

Lambert, N. M., Hartsough, C. S., Sassone, D., and Sandoval, J. (1987). Persistence of hyperactivity symptoms from childhood to adolescence and associated outcomes. Am. J. Orthopsychiatry 57, 22-32.

Langevin, R., and Curnoe, S. (2010). A comparison of psychopathy, attention deficit hyperactivity disorder, and brain dysfunction among sex offenders. J. Forens. Psychol. Practice $10,177-200$.

Langley, K., Fowler, T., Ford, T., Thapar, A. K., Van Den Bree, M., Harold, G., Owen, M. J., O’Donovan, M. C., and Thapar, A. (2010). Adolescent clinical outcomes for young people with attention-deficit hyperactivity disorder. Br. J. Psychiatry 196, 235-240.

Latimer, W. W., August, G. J., Newcomb, M. D., Realmuto, G. M., Hektner, J. M., and Mathy, R. M. (2003). Child and familial pathways to academic achievement and behavioral adjustment: a prospective sixyear study of children with and without ADHD. J. Atten. Disord. 7, 101-116.

Latimer, W. W., Ernst, J., Hennessey, J., Stinchfield, R. D., and Winters, K. C. (2004). Relapse among adolescent drug abusers following treatment: the role of probable ADHD Status. J. Child Adolesc. Subst. Abuse 13, 1-16.

Latimer, W. W., Stone, A. L., Voight, A., Winters, K. C., and August, G.
J. (2002). Gender differences in psychiatric comorbidity among adolescents with substance use disorders. Exp. Clin. Psychopharmacol. 10 310-315.

Lee, S. S., and Hinshaw, S. P. (2004). Severity of adolescent delinuency among boys with and without attention deficit hyperactivity disorder: predictions from early antisocial behavior and peer status. J. Clin. Child Adolesc. Psychol. 33, 705-716.

Lee, S. S., and Hinshaw, S. P. (2006). Predictors of adolescent functioning in girls with attention deficit hyperactivity disorder (ADHD): the role of childhood ADHD, conduct problems, and peer status. J. Clin. Child Adolesc. Psychol. 35, 356-368.

Leff, M. K., Moolchan, E. T., Cookus, B. A., Spurgeon, L., Evans, L. A., London, E. D., Kimes, A., Schroeder, J. R., and Ernst, M. (2003). Predictors of Smoking initiation among at risk youth: a controlled study. J. Child Adolesc. Subst. Abuse 13, 59-75.

Leibson, C. L., Katusic, S. K., Barbaresi, W. J., Ransom, J., and O'Brien, P. C. (2001). Use and costs of medical care for children and adolescents with and without attention-deficit/hyperactivity disorder. JAMA. 285, 60-66.

Levy, L. D., Fleming, J. P., and Klar, D. (2009). Treatment of refractory obesity in severely obese adults following management of newly diagnosed attention deficit hyperactivity disorder. Int. J. Obes. (Lond.) 33, 326-334.

Lifford, K. J., Harold, G. T., and Thapar, A. (2008). Parent-child relationships and ADHD symptoms: a longitudinal analysis. J. Abnorm. Child Psychol. 36, 285-296.

Lindberg, N., Tani, P., PorkkaHeiskanen, T., Appelberg, B., Rimón, R., and Virkkunen, M. (2004). ADHD and sleep in homicidal men with antisocial personality disorder. Neuropsychobiology 50, 41-47.

Loeber, R., Russo, M. F., StouthamerLoeber, M., and Lahey, B. B. (1994). Internalizing problems and their relation to the development of disruptive behaviors in adolescence. $J$. Res. Adolesc. 4, 615-637.

Lopez, B., Schwartz, S. J., Prado, G., Huang, S., Rothe, E. M., Wang, W., and Pantin, H. (2008). Correlates of early alcohol and drug use in hispanic adolescents: examining the role of adhd with comorbid conduct disorder, family, school, and peers. J. Clin. Child Adolesc. Psychol. 37, 820-832.
Luty, J., Sarkhel, A., O'Gara, C., and Umoh, O. (2007). Prevalence of childhood attention deficit hyperactivity disorder in opiate-dependent adults. Int. J. Psychiatry Clin. Pract. $11,157-162$.

Macdonald, V. M., and Achenbach, T. M. (1999). Attention problems versus conduct problems as 6-year predictors of signs of disturbance in a national sample. J. Am. Acad. Child Adolesc. Psychiatry 38, 1254-1261.

Malta, L. S., Blanchard, E. B., and Freidenberg, B. M. (2005). Psychiatric and behavioral problems in aggressive drivers. Behav. Res. Ther. 43, 1467-1484.

Mandell, D. S., Guevara, J. P., Rostain, A. L., and Hadley, T. R. (2003). Economic grand rounds: medical expenditures among children with psychiatric disorders in a Medicaid population. Psychiatr. Serv. 54, 465-467.

Mannuzza, S., Klein, R. G., Bessler, A., Malloy, P., and Hynes, M. E. (1997). Educational and occupational outcome of hyperactive boys grown up. J. Am. Acad. Child Adolesc. Psychiatry 36, 1222-1227.

Mannuzza, S., Klein, R. G., Bessler, A., Malloy, P., and Lapadula, M. (1993). Adult outcome of hyperactive boys: educational achievement, occupational rank, and psychiatric status. Arch. Gen. Psychiatry 50, 565-576.

Mannuzza, S., Klein, R. G., Bessler, A., Malloy, P., and Lapadula, M. (1998). Adult psychiatric status of hyperactive boys grown up. Am. J. Psychiatry 155, 493-498.

Mannuzza, S., Klein, R. G., Bonagura, N., Konig, P. H., and Shenker, R. (1988). Hyperactive boys almost grown up. II. Status of subjects without a mental disorder. Arch. Gen. Psychiatry 45, 13-18.

Mannuzza, S., Klein, R. G., Bonagura, N., Malloy, P., Giampino, T. L., and Addalli, K. A. (1991). Hyperactive boys almost grown up. V. Replication of psychiatric status. Arch. Gen. Psychiatry 48, 77-83.

Mannuzza, S., Klein, R. G., Konig, P. H., and Giampino, T. L. (1989). Hyperactive boys almost grown up: IV. Criminality and its relationship to psychiatric status. Arch. Gen. Psychiatry 46, 1073-1079.

Mannuzza, S., Klein, R. G., and Moulton, J. L. III. (2008a). Lifetime criminality among boys with ADHD: a prospective follow-up study into adulthood using official arrest records. Psychiatry Res. 160, 237-246.

Mannuzza, S., Klein, R. G., Truong, N. L., Moulton, J. L. III., Roizen, E. R., 
Howell, K. H., and Castellanos, F. X. (2008b). Age of methylphenidate treatment initiation in children with ADHD and later substance abuse: prospective follow-up into adulthood. Am. J. Psychiatry 165, 604-609.

Mannuzza, S., Klein, R. G., and Moulton Iii, J. L. (2002). Young adult outcome of children with "situational" hyperactivity: a prospective, controlled follow-up study. J. Abnorm. Child Psychol. 30, 191-198.

Marcus, S. C., Wan, G. J., Zhang, H. F., and Olfson, M. (2008). Injury among stimulant-treated youth with ADHD. J. Atten. Disord. 12, 64-69.

Marks, D. J., Mlodnicka, A., Bernstein, M., Chacko, A., Rose, S., and Halperin, J. M. (2009). Profiles of service utilization and the resultant economic impact in preschoolers with attention deficit/hyperactivity disorder. J. Pediatr. Psychol. 34, 681-689.

Marshal, M. P., Molina, B. S. G., Pelham, W. E., and Cheong, J. (2007). Attention-deficit hyperactivity disorder moderates the life stress pathway to alcohol problems in children of alcoholics. Alcohol. Clin. Exp. Res. 31, 564-574.

Massetti, G. M., Lahey, B. B., Pelham, W. E., Loney, J., Ehrhardt, A., Lee, S. S., and Kipp, H. (2008). Academic achievement over 8 years among children who met modified criteria for attentiondeficit/hyperactivity disorder at 46 years of age. J. Abnorm. Child Psychol. 36, 399-410.

Matsumoto, T., Yamaguchi, A., Asami, T., Kamijo, A., Iseki, E., Hirayasu, Y., and Wada, K. (2005). Drug preferences in illicit drug abusers with a childhood tendency of attention deficit/hyperactivity disorder: a study using the Wender Utah Rating Scale in a Japanese prison. Psychiatry Clin. Neurosci. 59, 311-318.

Matsuura, N., Hashimoto, T., and Toichi, M. (2009). A structural model of causal influence between aggression and psychological traits: survey of female correctional facility in Japan. Child. Youth Serv. Rev. 31, 577-583.

Matsuura, N., Hashimoto, T., and Toichi, M. (2010). The characteristics of $\mathrm{AD} / \mathrm{HD}$ symptoms, selfesteem, and aggression among serious juvenile offenders in Japan. Res. Dev. Disabil. 31, 1197-1203.

Mccormick, L. H. (2003). ADHD treatment and academic performance: a case series. J. Family Pract. 52, 620-624.
Mcgee, R., Partridge, F., Williams, S., and Silva, P. A. (1991). A twelve-year follow-up of preschool hyperactive children. J. Am. Acad .Child Adolesc. Psychiatry 30, 224-232.

Mcgee, R., Prior, M., Williams, S., Smart, D., and Sanson, A. (2002). The long-term significance of teacher-rated hyperactivity and reading ability in childhood: findings from two longitudinal studies. J. Child Psychol. Psychiatry 43, 1004-1017.

Mcmahon, R. J., Witkiewitz, K., and Kotler, J. S. (2010). Predictive validity of callous-unemotional traits measured in early adolescence with respect to multiple antisocial outcomes. J. Abnorm. Psychol. 119, 752-763.

Mcnamara, J., Vervaeke, S. L., and Willoughby, T. (2008). Learning disabilities and risk-taking behavior in adolescents: a comparison of those with and without comorbid attention-deficit/hyperactivity disorder. J. Learn. Disabil. 41, 561-574.

Messer, J., Maughan, B., Quinton, D., and Taylor, A. (2004). Precursors and correlates of criminal behaviour in women. Crim. Behav. Ment. Health 14, 82-107.

Miech, R. A., Caspi, A., Moffitt, T. E., Wright, B. R. E., and Silva, P. A. (1999). Low socioeconomic status and mental disorders: a Longitudinal Study of selection and causation during young adulthood. Am. J. Soc. 104, 1096-1131.

Mikami, A. Y., and Hinshaw, S. P. (2006). Resilient adolescent adjustment among girls: buffers of childhood peer rejection and attention-deficit/hyperactivity disorder. J. Abnorm. Child Psychol. 34, 825-839.

Mikami, A. Y., Hinshaw, S. P., Patterson, K. A., and Lee, J. C. (2008a). Eating pathology among adolescent girls with attention-deficit/hyperactivity disorder. J. Abnorm. Psychol. 117, 225-235.

Mikami, A. Y., Lee, S. S., Hinshaw, S. P., and Mullin, B. C. (2008b). Relationships between social information processing and aggression among adolescent girls with and without ADHD. J. Youth Adolesc. 37, 761-771.

Milberger, S., Biederman, J., Faraone, S. V., Chen, L., and Jones, J. (1997a). ADHD is associated with early initiation of cigarette smoking in children and adolescents. J. Am. Acad. Child Adolesc. Psychiatry 36, 37-44.

Milberger, S., Biederman, J., Faraone, S. V., Chen, L., and Jones, J. (1997b). Further evidence of an association between attentiondeficit/hyperactivity disorder and cigarette smoking: findings from a high-risk sample of siblings. Am. J. Addict. 6, 205-217.

Mill, J., Caspi, A., Williams, B. S., Craig, I., Taylor, A., Polo-Tomas, M., Berridge, C. W., Poulton, R., and Moffitt, T. E. (2006). Prediction of heterogeneity in intelligence and adult prognosis by genetic polymorphisms in the dopamine system among children with attention-deficit/hyperactivity disorder: evidence from 2 birth cohorts. Arch. Gen. Psychiatry 63, 462-469.

Miller, A. R., Brehaut, J. C., Raina, P., Mcgrail, K. M., and Armstrong, R. W. (2004). Use of medical services by methylphenidate-treated children in the general population. Ambul. Pediatr. 4, 174-180.

Miller-Johnson, S., Coie, J. D. Maumary-Gremaud, A., Bierman, K., and Group, C. P. P. R. (2002). Peer rejection and aggression and early starter models of conduct disorder. J. Abnorm. Child Psychol. 30, 217-230.

Minde, K., Eakin, L., Hechtman, L., Ochs, E., Bouffard, R., Greenfield, B., and Looper, K. (2003). The psychosocial functioning of children and spouses of adults with ADHD. J. Child Psychol. Psychiatry 44, 637-646.

Modestin, J., Matutat, B., and Wurmle, O. (2001). Antecedents of opioid dependence and personality disorder: attention-deficit/hyperactivity disorder and conduct disorder. Eur. Arch. Psychiatry Clin. Neurosci. 251, 42-47.

Moffitt, T. E. (1990). Juvenile delinquency and attention deficit disorder: boys' developmental trajectories from age 3 to age 15. Child Dev. 61 , 893.

Molina, B. S., Hinshaw, S. P., Swanson, J. M., Arnold, L. E., Vitiello, B., Jensen, P. S., Epstein, J. N., Hoza, B., Hechtman, L., Abikoff, H. B., Elliott, G. R., Greenhill, L. L., Newcorn, J. H., Wells, K. C., Wigal, T., Gibbons, R. D., Hur, K., and Houck, P. R. (2009). The MTA at 8 years: prospective follow-up of children treated for combined-type ADHD in a multisite study. J. Am. Acad. Child Adolesc. Psychiatry 48, 484-500.

Molina, B. S., Marshal, M. P., Pelham, W. E. Jr., and Wirth, R. J. (2005). Coping skills and parent support mediate the association between childhood attention-deficit/hyperactivity disorder and adolescent cigarette use. J. Pediatr. Psychol. 30, 345-357.
Molina, B. S. G., Flory, K., Hinshaw, S. P., Greiner, A. R., Arnold, L. E., Swanson, J. M., Hechtman, L., Jensen, P. S. Vitiello, B., Hoza, B., Pelham, W. E., Elliott, G. R., Wells, K. C., Abikoff, H. B., Gibbons, R. D., Marcus, S., Conners, C. K., Epstein, J. N., Greenhill, L. L., March, J. S., Newcorn, J. H., Severe, J. B., and Wigal, T. (2007a). Delinquent behavior and emerging substance use in the MTA at 36 months: prevalence, course, and treatment effects. J. Am. Acad. Child Adolesc. Psychiatry 46, 1028-1040.

Molina, B. S. G., Pelham, W. E., Gnagy, E. M., Thompson, A. L., and Marshal, M. P. (2007b). Attentiondeficit/hyperactivity disorder risk for heavy drinking and alcohol use disorder is age specific. Alcohol. Clin. Exp. Res. 31, 643-654.

Monuteaux, M. C., Faraone, S. V., Gross, L. M., and Biederman, J. (2007a). Predictors, clinical characteristics, and outcome of conduct disorder in girls with attentiondeficit/hyperactivity disorder: a longitudinal study. Psychol. Med. 37, 1731-1741.

Monuteaux, M. C., Spencer, T. J., Faraone, S. V., Wilson, A. M., and Biederman, J. (2007b). A randomized, placebo-controlled clinical trial of bupropion for the prevention of smoking in children and adolescents with attention-deficit/hyperactivity disorder. J. Clin. Psychiatry 68, 1094-1101.

Monuteaux, M. C., Wilens, T. E., and Biederman, J. (2007c). Does social class predict substance problems in young adults with ADHD? Am. $J$. Addict. 16, 403-409.

Morrison, J. R. (1980). Childhood hyperactivity in an adult psychiatric population: social factors. J. Clin. Psychiatry 41, 40-43.

Murphy, K., and Barkley, R. A. (1996). Attention deficit hyperactivity disorder adults: comorbidities and adaptive impairments. Compr. Psychiatry 37, 393-401.

Murphy, K. R., Barkley, R. A., and Bush, T. (2002). Young adults with attention deficit hyperactivity disorder: subtype differences in comorbidity, educational and clinical history. $J$. Nerv. Ment. Dis. 190, 147-157.

Murray, C., and Johnston, C. (2006). Parenting in mothers with and without attention-deficit/ hyperactivity disorder. J. Abnorm. Psychol. 115, 52-61.

Murray, J., Irving, B., Farrington, D. P., Colman, I., and Bloxsom, C. A. J. (2010). Very early predictors of conduct problems and crime: results from a national cohort study. 
J. Child Psychol. Psychiatry 51, 1198-1207.

Murray-Close, D., Hoza, B., Hinshaw, S. P., Arnold, L. E., Swanson, J., Jensen, P. S., Hechtman, L., and Wells, K. (2010). Developmental processes in peer problems of children with attentiondeficit/hyperactivity disorder in the multimodal treatment study of children with ADHD: developmental cascades and vicious cycles. Dev. Psychopathol. 22, 785-802.

Musser, C. J., Ahmann, P. A., Theye, F. W., Mundt, P., Broste, S. K., and Mueller-Rizner, N. (1998). Stimulant use and the potential for abuse in Wisconsin as reported by school administrators and longitudinally followed children. J. Dev. Behav. Pediatr. 19, 187-192.

Nada-Raja, S., Langley, J. D., Mcgee, R., Williams, S. M., Begg, D. J., and Reeder, A. I. (1997). Inattentive and hyperactive behaviors and driving offenses in adolescence. J. Am. Acad. Child Adolesc. Psychiatry 36, 515-522.

Nhtsa. (1997). Driving histories of ADHD subjects. National highway traffic safety administration. Ann. Emerg. Med. 29, 546-547; discussion 547-548.

Nigg, J. T., Wong, M. M., Martel, M. M., Jester, J. M., Puttler, L. I., Glass, J. M., Adams, K. M., Fitzgerald, H. E., and Zucker, R. A. (2006). Poor response inhibition as a predictor of problem drinking and illicit drug use in adolescents at risk for alcoholism and other substance use disorders. $J$. Am. Acad. Child Adolesc. Psychiatry 45, 468-475.

Ninowski, J. E., Mash, E. J., and Benzies, K. M. (2007). Symptoms of attention-deficit/hyperactivity disorder in first-time expectant women: relations with parenting cognitions and behaviors. Infant Ment. Health J. $28,54-75$.

Nixon, S. J., Tivis, R., and Parsons, O. A. (1995). Behavioral dysfunction and cognitive efficiency in male and female alcoholics. Alcohol. Clin. Exp. Res. 19, 577-581

Norvilitis, J. M., Sun, L., and Zhang, J. (2010). ADHD symptomatology and adjustment to college in China and the United States. J. Learn. Disabil. 43, 86-94.

Ohlmeier, M. D., Peters, K., Te Wildt, B. T., Zedler, M., Ziegenbein, M., Wiese, B., Emrich, H. M., and Schneider, U. (2008). Comorbidity of alcohol and substance dependence with attention-deficit/hyperactivity disorder (ADHD). Alcohol Alcohol. 43, 300-304.
Olfson, M., Gameroff, M. J., Marcus, S. C., and Jensen, P. S. (2003). National trends in the treatment of attention deficit hyperactivity disorder. Am. J. Psychiatry 160, 1071-1077.

Owens, E. B., Hinshaw, S. P., Lee, S. S., and Lahey, B. B. (2009). Few girls with childhood attentiondeficit/hyperactivity disorder show positive adjustment during adolescence. J. Clin. Child Adolesc. Psychol. 38, 132-143.

Owens, M. R., and Bergman, A. (2010). Alcohol use and antisocial behavior in late adolescence: characteristics of a sample attending a GED program. J. Child Adolesc. Subst. Abuse 19, 78-98.

Pagoto, S. L., Curtin, C., Lemon, S. C., Bandini, L. G., Schneider, K. L., Bodenlos, J. S., and Ma, Y. (2009). Association between adult attention deficit/hyperactivity disorder and obesity in the US population. Obesity 17, 539-544.

Pardini, D., Obradovic, J., and Loeber, R. (2006). Interpersonal callousness, hyperactivity/impulsivity, inattention, and conduct problems as precursors to delinquency persistence in boys: a comparison of three grade-based cohorts. J. Clin. Child Adolesc. Psychol. 35, 46-59.

Pardini, D., White, H. R., and Stouthamer-Loeber, M. (2007). Early adolescent psychopathology as a predictor of alcohol use disorders by young adulthood. Drug Alcohol Depend. 88(Suppl. 1), S38-S49.

Pardini, D. A., and Fite, P. J. (2010). Symptoms of conduct disorder, oppositional defiant disorder, attention-deficit/hyperactivity disorder, and callous-unemotional traits as unique predictors of psychosocial maladjustment in boys: advancing an evidence base for DSM-V. J. Am. Acad. Child Adolesc. Psychiatry 49, 1134-1144.

Paternite, C. E., Loney, J., Salisbury, H., and Whaley, M. A. (1999). Childhood inattention-overactivity, aggression, and stimulant medication history as predictors of young adult outcomes. J. Child Adolesc. Psychopharmacol. 9, 169-184.

Pomerleau, O. F., Downey, K. K., Stelson, F. W., and Pomerleau, C. S. (1995). Cigarette smoking in adult patients diagnosed with attention deficit hyperactivity disorder. $J$. Subst. Abuse 7, 373-378.

Pope, A. W., Bierman, K. L., and Mumma, G. H. (1989). Relations between hyperactive and aggressive behavior and peer relations at three elementary grade levels. J. Abnorm. Child Psychol. 17, 253-267.
Powers, R. L., Marks, D. J., Miller, C. J., Newcorn, J. H., and Halperin, J. M. (2008). Stimulant treatment in children with attentiondeficit/hyperactivity disorder moderates adolescent academic outcome. J. Child Adolesc. Psychopharmacol. 18, 449-459.

Preuss, U., Ralston, S. J., Baldursson, G., Falissard, B., Lorenzo, M. J., Pereira, R. R., Vlasveld, L., Coghill, D., and Group, A. S. (2006). Study design, baseline patient characteristics and intervention in a crosscultural framework: results from the ADORE study. Eur. Child Adolesc. Psychiatry 15, 4-19.

Putninš, A. L. (2005). Correlates and predictors of self-reported suicide attempts among incarcerated youths. Int. J. Offender Ther. Comp. Criminol. 49, 143-157.

Rabiner, D. L., Anastopoulos, A. D., Costello, J., Hoyle, R. H., and Swartzwelder, H. S. (2008). Adjustment to college in students with ADHD. J. Atten. Disord. 11, 689-699.

Rabiner, D. L., Coie, J. D., MillerJohnson, S., Boykin, A.-S. M., and Lochman, J. E. (2005). Predicting the persistence of aggressive offending of african american males from adolescence into young adulthood: the importance of peer relations, aggressive behavior, and ADHD symptoms. J. Emot. Behav. Disord. 13, 131-140.

Rasmussen, K., and Levander, S. (2009). Untreated ADHD in adults: are there sex differences in symptoms, comorbidity, and impairment? J. Atten Disord. 12, 353-360.

Rasmussen, P., and Gillberg, C. (2000). Natural outcome of ADHD with developmental coordination disorder at age 22 years: a controlled, longitudinal, community-based study. J. Am. Acad. Child Adolesc. Psychiatry 39, 1424-1431.

Realmuto, G. M., Winters, K. C., August, G. J., Lee, S., Fahnhorst, T., and Botzet, A. (2009). Drug use and psychosocial functioning of a community-derived sample of adolescents with childhood ADHD. J. Child Adolesc. Subst. Abuse 18, 172-192.

Reimer, B., D'Ambrosio, L. A., Coughlin, J. F., Fried, R., and Biederman, J. (2007). Task-induced fatigue and collisions in adult drivers with attention deficit hyperactivity disorder. Traffic Inj. Prev. 8, 290-299.

Reimer, B., D'Ambrosio, L. A., Gilbert, J., Coughlin, J. F., Biederman, J., Surman, C., Fried, R., and Aleardi, M.
(2005). Behavior differences in drivers with attention deficit hyperactivity disorder: the driving behavior questionnaire. Accid. Anal. Prev. 37, 996-1004.

Retz, W., Retz-Junginger, P., Hengesch, G., Schneider, M., Thome, J., Pajonk, F. G., Salahi-Disfan, A., Rees, O., Wender, P. H., and Rosler, M. (2004). Psychometric and psychopathological characterization of young male prison inmates with and without attention deficit/hyperactivity disorder. Eur. Arch. Psychiatry Clin. Neurosci. 254, 201-208.

Richards, T. L., Deffenbacher, J. L., and Rosén, L. A. (2002). Driving anger and other driving-related behaviors in high and low ADHD symptom college students. J. Atten. Disord. 6, 25-38.

Richards, T. L., Deffenbacher, J. L. Rosen, L. A., Barkley, R. A., and Rodricks, T. (2006). Driving anger and driving behavior in adults with ADHD. J. Atten. Disord. 10, 54-64.

Rodriguez, D., Tercyak, K. P., and Audrain-Mcgovern, J. (2008). Effects of inattention and hyperactivity/impulsivity symptoms on development of nicotine dependence from mid adolescence to young adulthood. J. Pediatr. Psychol. 33, 563-575.

Rojo, L., Ruiz, E., Domínguez, J. A., Calaf, M., and Livianos, L. (2006). Comorbidity between obesity and attention deficit/hyperactivity disorder: population study with 13-15year-olds. Int. J. Eat. Disord. 39, 519-522.

Rösler, M., Retz, W., Retz-Junginger, P., Hengesch, G., Schneider, M., Supprian, T., Schwitzgebel, P., Pinhard, K., Dovi-Akue, N., Wender, P., and Thome, J. (2004). Prevalence of attention deficit-/hyperactivity disorder (ADHD) and comorbid disorders in young male prison inmates. Eur. Arch. Psychiatry Clin. Neurosci. 254, 365-371.

Rösler, M., Retz, W., Yaqoobi, K., Burg, E., and Retz-Junginger, P. (2009). Attention deficit/hyperactivity disorder in female offenders: prevalence, psychiatric comorbidity and psychosocial implications. Eur. Arch. Psychiatry Clin. Neurosci. 259, 98-105.

Ruchkin, V., Lorberg, B., Koposov, R., Schwab-Stone, M., and Sukhodolsky, D. G. (2008). ADHD symptoms and associated psychopathology in a community sample of adolescents from the European North of Russia. J. Atten. Disord. 12 54-63. 
Rucklidge, J. J., and Tannock, R. (2001). Psychiatric, psychosocial, and cognitive functioning of female adolescents with ADHD. J. Am. Acad. Child Adolesc. Psychiatry 40, 530-540.

Sartor, C. E., Lynskey, M. T., Heath, A. C., Jacob, T., and True, W. (2007). The role of childhood risk factors in initiation of alcohol use and progression to alcohol dependence. Addiction 102, 216-225.

Satterfield, J. H., Faller, K. J., Crinella, F. M., Schell, A. M., Swanson, J. M., and Homer, L. D. (2007). A 30-year prospective follow-up study of hyperactive boys with conduct problems: adult criminality. $J$. Am. Acad. Child Adolesc. Psychiatry $46,601$.

Satterfield, J. H., Hoppe, C. M., and Schell, A. M. (1982). A prospective study of delinquency in 110 adolescent boys with attention deficit disorder and 88 normal adolescent boys. Am. J. Psychiatry 139, 795-798.

Satterfield, J. H., Satterfield, B. T., and Cantwell, D. P. (1981). Three-year multimodality treatment study of 100 hyperactive boys. J. Pediatr. 98, 650-655.

Satterfield, J. H., Satterfield, B. T., and Schell, A. M. (1987). Therapeutic interventions to prevent delinquency in hyperactive boys. J. Am. Acad. Child Adolesc. Psychiatry 26, 56-64

Satterfield, J. H., and Schell, A. (1997). A prospective study of hyperactive boys with conduct problems and normal boys: adolescent and adult criminality. J. Am. Acad. Child Adolesc. Psychiatry 36, 1726-1735.

Satterfield, J. H., Swanson, J., Schell, A. M., and Lee, F. (1994). Prediction of antisocial behavior in attentiondeficit hyperactivity disorder boys from aggression/defiant scores. J. Am. Acad. Child Adolesc. Psychiatry 33, 185-190.

Savolainen, J., Hurtig, T. M., Ebeling, H. E., Moilanen, I. K., Hughes, L. A., and Taanila, A. M. (2010). Attention deficit hyperactivity disorder (ADHD) and criminal behaviour: the role of adolescent marginalization. Eur. J. Criminol. 7, 442-459.

Sayal, K., Owen, V., White, K., Merrell, C., Tymms, P., and Taylor, E. (2010). Impact of early school-based screening and intervention programs for ADHD on children's outcomes and access to services: follow-up of a school-based trial at age 10 years. Arch. Pediatr. Adolesc. Med. 164, 462-469.

Scheffler, R. M., Brown, T. T., Fulton, B. D., Hinshaw, S. P., Levine,
P., and Stone, S. (2009). Positive association between attentiondeficit/hyperactivity disorder medication use and academic achievement during elementary school. Pediatrics 123, 1273-1279.

Schubiner, H., Tzelepis, A., Milberger, S., Lockhart, N., Kruger, M., Kelley, B. J., and Schoener, E. P. (2000). Prevalence of attentiondeficit/hyperactivity disorder and conduct disorder among substance abusers. J. Clin. Psychiatry 61, 244-251.

Schultz, B. K., Evans, S. W., and Serpell, Z. N. (2009). Preventing failure among middle school students with attention deficit hyperactivity disorder: a survival analysis. School Psych. Rev. 38, 14-27.

Schwartz, D., Mcfadyen-Ketchum, S., Dodge, K. A., Pettit, G. S., and Bates, J. E. (1999). Early behavior problems as a predictor of later peer group victimization: moderators and mediators in the pathways of social risk. $J$. Abnorm. Child. Psychol. 27, 191-201.

Secnik, K., Swensen, A., and Lage, M. J. (2005). Comorbidities and costs of adult patients diagnosed with attention-deficit hyperactivity disorder. Pharmacoeconomics 23 , 93-102.

Seidman, L. J., Biederman, J., Weber, W., Hatch, M., and Faraone, S. V. (1998). Neuropsychological function in adults with attention-deficit hyperactivity disorder. Biol. Psychiatry 44, 260-268.

Shaffer, H. J., Nelson, S. E., Laplante, D. A., Labrie, R. A., Albanese, M., and Caro, G. (2007). The epidemiology of psychiatric disorders among repeat DUI offenders accepting a treatment-sentencing option. J. Consult. Clin. Psychol. 75, 795-804.

Shaw-Zirt, B., Popali-Lehane, L., Chaplin, W., and Bergman, A. (2005). Adjustment, social skills, and selfesteem in college students with symptoms of ADHD. J. Atten. Disord. 8, 109-120.

Shifrin, J. G., Proctor, B. E., and Prevatt, F. F. (2010). Work performance differences between college students with and without ADHD. J. Atten. Disord. 13, 489-496.

Sibley, M. H., Evans, S. W., and Serpell, Z. N. (2010). Social cognition and interpersonal impairment in young adolescents with ADHD. J. Psychopathol. Behav. Assess. 32, 193-202.

Siponmaa, L., Kristiansson, M., Jonson, C., Nyden, A., and Gillberg, C. (2001). Juvenile and young adult mentally disordered offenders: the role of child neuropsychiatric disorders. J. Am. Acad. Psychiatry Law 29 , 420-426.

Sizoo, B., Van Den Brink, W., Koeter M., Gorissen Van Eenige, M., Van Wijngaarden-Cremers, P., and Van Der Gaag, R. J. (2010). Treatment seeking adults with autism or ADHD and co-morbid substance use disorder: prevalence, risk factors and functional disability. Drug Alcohol Depend. 107, 44-50.

Slomkowski, C., Klein, R. G., and Mannuzza, S. (1995). Is self-esteem an important outcome in hyperactive children? J. Abnorm. Child. Psychol. 23, 303-315.

Sobanski, E., Brüggemann, D., Alm, B., Kern, S., Deschner, M., Schubert, T., Philipsen, A., and Rietschel, M. (2007). Psychiatric comorbidity and functional impairment in a clinically referred sample of adults with attention-deficit/hyperactivity disorder (ADHD). Eur. Arch. Psychiatry Clin. Neurosci. 257, 371-377.

Sobanski, E., Brüggemann, D., Alm, B., Kern, S., Philipsen, A., Schmalzried, H., Heßlinger, B., Waschkowski, H., and Rietschel, M. (2008a). Subtype differences in adults with attention-deficit/hyperactivity disorder (ADHD) with regard to ADHD-symptoms, psychiatric comorbidity and psychosocial adjustment. Eur. Psychiatry 23, 142-149.

Sobanski, E., Sabljic, D., Alm, B., Skopp, G., Kettler, N., Mattern, R., and Strohbeck-Kuhner, P. (2008b). Driving-related risks and impact of methylphenidate treatment on driving in adults with attentiondeficit/hyperactivity disorder (ADHD). J. Neural Transm. 115, 347-356.

Sourander, A., Elonheimo, H., Niemela, S., Nuutila, A.-M., Helenius, H., Sillanmaki, L., Piha, J., Tamminen, T., Kumpulainen, K., Moilanen, I., and Almqvist, F. (2006). Childhood predictors of male criminality: a prospective population-based follow-up study from age 8 to late adolescence. J. Am. Acad. Child Adolesc. Psychiatry 45, 578-586.

Stormont, M. (2000). Early child risk factors for externalizing and internalizing behaviors: a 5-year followforward assessment. J. Early Interv. 23, 180-190.

Szatmari, P., Offord, D. R., and Boyle, M. H. (1989). Correlates, associated impairments and patterns of service utilization of children with attention deficit disorder: findings from the Ontario Child Health Study. J. Child Psychol. Psychiatry 30, 205-217.
Szobot, C. M., Rohde, L. A., Bukstein, O., Molina, B. S. G., Martins, C., Ruaro, P., and Pechansky, F. (2007). Is attention-deficit/hyperactivity disorder associated with illicit substance use disorders in male adolescents? A community-based case-control study. Addiction 102, 1122-1130.

Takser, L., Dellatolas, G., Bowler, R., Laplante, N., and Huel, G. (2002). Predictive factors of manual dexterity and cognitive performance at 17 years: a 10-year longitudinal study in a rural area of France. Percept. Mot. Skills 95, 15-26.

Tang, Y.-L., Kranzler, H. R., Gelernter, J., Farrer, L. A., and Cubells, J. F. (2007). Comorbid psychiatric diagnoses and their association with cocaine-induced psychosis in cocaine-dependent subjects. Am. J. Addict. 16, 343-351.

Tarter, R. E. (1982). Psychosocial history, minimal brain dysfunction and differential drinking patterns of male alcoholics. J. Clin. Psychol. 38, 867-873.

Tarter, R. E., Kirisci, L., Feske, U., and Vanyukov, M. (2007). Modeling the pathways linking childhood hyperactivity and substance use disorder in young adulthood. Psychol. Addict. Behav. 21, 266-271.

Taylor, E., Chadwick, O., Heptinstall, E., and Danckaerts, M. (1996). Hyperactivity and conduct problems as risk factors for adolescent development. J. Am. Acad. Child Adolesc. Psychiatry 35, 1213-1226.

Tercyak, K. P., Lerman, C., and Audrain, J. (2002). Association of attentiondeficit/hyperactivity disorder symptoms with levels of cigarette smoking in a community sample of adolescents. J. Am. Acad. Child Adolesc. Psychiatry 41, 799-805.

Thompson, A. L., Molina, B. S. G., Pelham, W. Jr., and Gnagy, E. M. (2007). Risky driving in adolescents and young adults with childhood ADHD. J. Pediatr. Psychol. 32, 745-759.

Toren, P., Ratner, S., Weizman, A., Lask, M., Ben-Amitay, G., and Laor, N. (2007). Reboxetine maintenance treatment in children with attention-deficit/hyperactivity disorder: a long-term follow-up study. J. Child Adolesc. Psychopharmacol. $17,803-812$.

Torgersen, T., Gjervan, B., and Rasmussen, K. (2006). ADHD in adults: a study of clinical characteristics, impairment and comorbidity. Nord. J. Psychiatry 60, 38-43.

Trampush, J. W., Miller, C. J., Newcorn, J. H., and Halperin, J. M. (2009). 
The impact of childhood ADHD on dropping out of high school in urban adolescents/young adults. J. Atten. Disord. 13, 127-136.

Tymms, P., and Merrell, C. (2006). The impact of screening and advice on inattentive, hyperactive and impulsive children. Eur. J. Special Needs Educ. 21, 321-337.

Upadhyaya, H. P., Rose, K., Wang, W., O’Rourke, K., Sullivan, B., Deas, D., and Brady, K. T. (2005). Attentiondeficit/hyperactivity disorder, medication treatment, and substance use patterns among adolescents and young adults. J. Child Adolesc. Psychopharmacol. 15, 799-809.

Velting, O. N., and Whitehurst, G. J. (1997). Inattention-hyperactivity and reading achievement in children from low-income families: a longitudinal model. J. Abnorm. Child. Psychol. 25, 321-331.

Vitaro, F., and Tremblay, R. E. (1994). Impact of a prevention program on aggressive children's friendships and social adjustment. J. Abnorm. Child. Psychol. 22, 457-475.

Vitelli, R. (1996). Prevalence of childhood conduct and attention-deficit hyperactivity disorders in adult maximum-security inmates. Int. J. Offender Ther. Comp. Criminol. 40, 263-271.

Volpe, R. J., Dupaul, G. J., Jitendra, A. K., and Tresco, K. E. (2009). Consultation-based academic interventions for children with attention deficit hyperactivity disorder: effects on reading and mathematics outcomes at 1-year follow-up. School Psych. Rev. 38, 5-13.

Wåhlstedt, C., Thorell, L. B., and Bohlin, G. (2008). ADHD symptoms and executive function impairment: early predictors of later behavioral problems. Dev. Neuropsychol. 33, 160-178.

Waldrop, R. D. (1994). Selection of patients for management of attention deficit hyperactivity disorder in a private practice setting. Clin. Pediatr. (Phila.) 33, 83-87.

Walker, L. R., Abraham, A. A., and Tercyak, K. P. (2010). Adolescent caffeine use, ADHD, and cigarette smoking. Child. Health Care 39, 73-90.
Wallander, J. L. (1988). The relationship between attention problems in childhood and antisocial behavior eight years later. J. Child Psychol. Psychiatry 29, 53-61.

Waring, M. E., and Lapane, K. L. (2008). Overweight in children and adolescents in relation to attention-deficit/hyperactivity disorder: results from a national sample. Pediatrics 122, e1-e6.

Weafer, J., Camarillo, D., Fillmore, M. T., Milich, R., and Marczinski, C. A. (2008). Simulated driving performance of adults with ADHD: comparisons with alcohol intoxication. Exp. Clin. Psychopharmacol. 16, 251-263.

Weiss, G., Hechtman, L., Milroy, T., and Perlman, T. (1985). Psychiatric status of hyperactives as adults: a controlled prospective 15-year followup of 63 hyperactive children. $J$. Am. Acad. Child Psychiatry 24, 211-220.

Weithorn, C. J., and Marcus, M. (1985). High-active children and achievement tests: a two-year follow-up. Psychol. Sch. 22, 449-458.

Westmoreland, P., Gunter, T., Loveless, P., Allen, J., Sieleni, B., and Black, D. W. (2010). Attention deficit hyperactivity disorder in men and women newly committed to prison. Int. J. Offender Ther. Comp. Criminol. 54, 361-377.

Whalen, C. K., Jamner, L. D., Henker, B., Delfino, R. J., and Lozano, J. M. (2002). The ADHD spectrum and everyday life: experience sampling of adolescent moods, activities, smoking, and drinking. Child Dev. 73, 209-227.

Whalen, C. K., Jamner, L. D., Henker, B., Gehricke, J.-G., and King, P. S. (2003). Is there a link between adolescent cigarette smoking and pharmacotherapy for ADHD? Psychol. Addict. Behav. 17, 332-335.

Whitmore, E. A., Mikulich, S. K., Ehlers, K. M., and Crowley, T. J. (2000). One-year outcome of adolescent females referred for conduct disorder and substance abuse/dependence. Drug Alcohol Depend. 59, 131-141.

Wiegartz, P. S., Bair, J. P., Besyner, J. K., Cox, W. M., and Seidenberg, M.
(1996). Assessment of attentiondeficit/hyperactivity disorder in adult alcoholics. J. Atten. Disord. 1, 87-94.

Wilens, T. E., Adamson, J., Sgambati, S. Whitley, J., Santry, A., Monuteaux, M. C., and Biederman, J. (2007). Do individuals with ADHD selfmedicate with cigarettes and substances of abuse? Results from a Controlled Family Study of ADHD. Am. J. Addict. 16, 14-23.

Wilens, T. E., Biederman, J., and Mick, E. (1998). Does ADHD affect the course of substance abuse? Findings from a sample of adults with and without ADHD. Am. J. Addict. 7 , 156-163.

Wilens, T. E., Biederman, J., Mick, E., Faraone, S. V., and Spencer, T. (1997). Attention deficit hyperactivity disorder (ADHD) is associated with early onset substance abuse. $J$. Nerv. Ment. Dis. 185, 475-482.

Wilens, T. E., Gignac, M., Swezey, A., Monuteaux, M. C., and Biederman, J. (2006). Characteristics of adolescents and young adults with adhd who divert or misuse their prescribed medications. J. Am. Acad. Child Adolesc. Psychiatry 45, 408-414.

Wilens, T. E., Vitulano, M., Upadhyaya, H., Adamson, J., Sawtelle, R., Utzinger, L., and Biederman, J. (2008). Cigarette smoking associated with attention deficit hyperactivity disorder. J. Pediatr. 153, 414-419.

Willcutt, E. G., Betjemann, R. S., Pennington, B. F., Olson, R. K., Defries, J. C., and Wadsworth, S. J. (2007). Longitudinal study of reading disability and attention-deficit/hyperactivity disorder: implications for education. Mind Brain Educ. 1, 181-192.

Willoughby, M. T., Kollins, S. H., Mcclernon, F. J., and Group, T. F. L. I. (2009). Association between smoking and retrospectively reported attention-deficit/hyperactivity disorder symptoms in a large sample of new mothers. Nicotine Tob. Res. 11, 313-322.

Wilson, J. M., and Marcotte, A. C. (1996). Psychosocial adjustment and educational outcome in adolescents with a childhood diagnosis of attention deficit disorder. J. Am. Acad. Child Adolesc. Psychiatry 35, 579-587.

Windle, M. (1993). A retrospective measure of childhood behavior problems and its use in predicting adolescent problem behaviors. J. Stud. Alcohol. 54, 422-431.

Wodushek, T. R., and Neumann, C. S. (2003). Inhibitory capacity in adults with symptoms of attention deficit/hyperactivity disorder (ADHD). Arch. Clin. Neuropsychol. $18,317-330$.

Woodward, L. J., Fergusson, D. M., and Horwood, L. J. (2000). Driving outcomes of young people with attentional difficulties in adolescence. $J$. Am. Acad. Child Adolesc. Psychiatry 39, 627-634.

Yan, W. (1996). An investigation of adult outcome of hyperactive children in Shanghai. Chin. Med. J. 109, 877-880.

Young, S., Chadwick, O., Heptinstall, E., Taylor, E., and SonugaBarke, E. J. (2005a). The adolescent outcome of hyperactive girls. Self-reported interpersonal relationships and coping mechanisms. Eur. Child Adolesc. Psychiatry 14, 245-253.

Young, S., Heptinstall, E., Sonuga-Barke, E. J., Chadwick, O., and Taylor, E. (2005b). The adolescent outcome of hyperactive girls: self-report of psychosocial status. J. Child Psychol. Psychiatry 46, 255-262.

Young, S., Gudjonsson, G., Ball, S. and Lam, J. (2003). Attention deficit hyperactivity disorder (ADHD) in personality disordered offenders and the association with disruptive behavioural problems. J. Forens. Psychiatry Psychol. 14 491-505.

Young, S., and Gudjonsson, G. H. (2006). ADHD symptomatology and its relationship with emotional, social and delinquency problems. Psychol. Crime Law 12, 463-471.

Young, S., and Gudjonsson, G. H. (2008). Growing out of ADHD: the relationship between functioning and symptoms. J. Atten. Disord. $12,162-169$. 